\title{
Time Trends of Persistent Organic Pollutants in Benthic and Pelagic Indicator Fishes from Puget Sound, Washington, USA
}

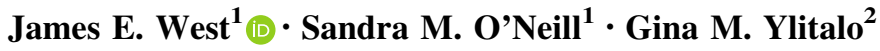

Received: 9 September 2016/Accepted: 20 January 2017/Published online: 20 May 2017

(C) The Author(s) 2017. This article is published with open access at Springerlink.com

\begin{abstract}
We modeled temporal trends in polychlorinated biphenyls (PCBs), polybrominated diphenyl ethers (PBDEs), and dichlorodiphenyltrichloroethane and its metabolites (DDTs) in two indicator fish species representing benthic and pelagic habitats in Puget Sound, Washington, USA. English sole (Parophrys vetulus, benthic) index sites and larger-scale Pacific herring (Clupea pallasii, pelagic) foraging areas represented a wide range of possible contamination conditions, with sampling locations situated adjacent to watersheds exhibiting high, medium and low development. Consistency in analytical data throughout the study was maintained by either calculating method-bias-correction factors on paired samples as methods evolved or by analyzing older archived samples by current methods. PCBs declined moderately in two herring stocks from a low-development basin (2.3 and $4.0 \%$ annual rate of decline) and showed no change in the highly developed and moderately developed basins during a 16- to 21-year period. PCBs increased in English sole from four of ten sites $(2.9-7.1 \%)$, and the remaining six exhibited no significant change. PBDEs and DDTs declined significantly in all herring stocks $(4.2-8.1 \%)$, although analytical challenges warrant caution in
\end{abstract}

James E. West

james.west@dfw.wa.gov

1 Marine Resources Division, Washington Department of Fish and Wildlife, 600 Capitol Way N, Olympia, WA 98501, USA

2 Environmental and Fisheries Sciences Division, Northwest Fisheries Science Center, National Marine Fisheries Service, National Oceanic and Atmospheric Administration, 2725 Montlake Boulevard East, Seattle, WA 98112, USA interpreting DDT results. PBDEs declined in English sole from two high-development and one low-development site $(3.7-7.2 \%)$ and remained unchanged in the remaining seven. DDTs increased in English sole from one high-development site (Tacoma City Waterway) and declined in two high-development and one low development site. As with herring, analytical challenges warrant caution in interpreting the English sole DDT results. It is likely that source controls and mitigation efforts have contributed to the declines in PBDEs and DDTs overall, whereas PCBs appear to have persisted, especially in the pelagic food web, despite bans in PCB production and use.

Although the production and use of a number of persistent organic pollutants (POPs) has been curtailed to protect environmental and human health in many countries (Tierney et al. 2014), it can be difficult to evaluate the success of these efforts over the long term, especially in aquatic environments. POPs include a wide variety of toxic industrial chemicals such as polychlorinated biphenyls (PCBs) and flame-retardant polybrominated diphenyl ethers (PBDEs), as well as chlorinated pesticides such as dichlorodiphenyltrichloroethane and its metabolites (DDTs), chlordanes, and hexachlorobenzene. These POPs can accumulate in sediments and biota where they may persist for many years (Jones and de Voogt 1999; Tierney et al. 2014). Earliest efforts to measure the level of POP contamination in marine animals (DDTs and PCBs; Jensen et al. 1969) combined with more recent time trend analyses suggest that many aquatic systems exhibited a substantial drop in DDTs and PCBs through the 1970s and 1980s [e.g., the Canadian arctic (Braune et al. 2005), the Baltic Sea (Bignert et al. 1998), and the Great Lakes of North America (Stow et al. 1994)]. Variation in biological 
covariates, such as fish age, lipid levels, sex, and trophic level, can confound analysis of temporal and spatial trends in biota (West et al. 2008), as well as comparisons between studies (this report). Moreover, it is difficult to maintain consistency in measuring POPs as analytical methods evolve over time.

The production and use of DDTs and PCB technical mixtures in the United States were sharply curtailed from 1972 to 1979 , resulting from federal legislation banning these chemicals. In addition, Washington State passed legislation in 2008 to restrict the use of polybrominated diphenylether (PBDE) flame retardants. Washington State monitors the concentration of these three chemical groups in two marine indicator fish species representing benthic (English sole, Parophrys vetulus) and pelagic (Pacific herring, Clupea pallasii) habitats as part of a directed effort to track the health the Puget Sound ecosystem. Tissue residue recovery targets using the concept of critical POP body residues (Meador et al. 2011) are used to evaluate the success of pollution remediation efforts, on a large, ecosystem scale. The two Puget Sound fish contaminant indicators (species) reported here are part of a larger portfolio of Vital Sign indicators designed to simplify science reporting and link it to regional policy, ultimately resulting in easily communicated policy statements or targets that define the desired condition or goals (Puget Sound Partnership 2016).

Puget Sound comprises a complex, fjord-like, interconnected series of inland marine and estuarine waters in Washington State (Burns 1985; Moore et al. 2008) that exchange with the Pacific Ocean primarily via a relatively narrow waterway, the Strait of Juan de Fuca (Fig. 1). Oceanographic stratification and geographically restricted connections between deep Puget Sound basins result in recirculation of basin waters (Thomson 1994), which increases retention of regionally produced pollutants (Harrison et al. 1994). These inland marine waters drain watersheds that range from highly developed or urbanized with large cities (central Puget Sound) to moderately developed (southern Puget Sound), to rural, undeveloped lands (northern Puget Sound), resulting in marine waters that range from highly polluted to nearly pristine.

Previous studies have reported high levels of POPs throughout Puget Sound's pelagic food web including its phytoplankton and zooplankton prey base (West et al. 2011a), secondary consumers, such as Pacific herring (West et al. 2008), tertiary consumers, such as Chinook salmon, Oncorhynchus tshawytscha (O'Neill and West 2009; Cullon et al. 2009) and gadoid codfishes (West et al. 2011b), and apex predators, including pelagic-fish-eating killer whales, Orcinus orca (Ross et al. 2000; Ross 2006, Ross et al. 2009; Krahn et al. 2007, 2009) and harbor seals, Phoca vitulina (Ross et al. 2004, 2013; Cullon et al. 2005).
Based on results from these studies, POPs in these species illustrate broad, basin-wide contaminant conditions in the pelagic food web.

Ross et al. (2013) identified strongly declining trends in concentrations of PCBs from 1984 to 2010 and one other POP class (polychlorinated naphthalenes) from 1984 to 2003 in harbor seals from Southern Puget Sound. PBDEs in the same harbor seals showed a different temporal pattern, with a strong increase from 1984 to 2003 and a subsequent $40 \%$ decline in 2009. More recent POP trends in Puget Sound marine mammals remain unknown, although Hickie et al. (2007) predicted it would take between 14 and 57 years for PCB concentration to fall below an effects threshold of $17 \mathrm{mg}$ total PCBs/kg blubber lipids for the populations of fish-eating killer whales that typically forage in Puget Sound.

Contamination of pelagic species with POPs has occurred at a large, basin scale in Puget Sound, whereas POP contamination of benthic and sessile species appears to be limited to urbanized areas, which is where the greatest sediment contamination occurs (Long et al. 2005). This is evident from POPs reported in blue mussels (Mytilus trossulus; Lanksbury et al. 2013) and English sole in Puget Sound (this report and Ylitalo et al. 1999), and consistent with other species from the California Coast (Dodder et al. 2013) and San Francisco Bay (Davis et al. 2007; Greenfield and Allen 2013).

The Washington Department of Fish and Wildlife (WDFW) has tracked POPs in indicator species representing key food-web pathways including English sole, a bottom-dwelling flatfish, as well as Pacific herring, a small, schooling mid-water planktivore, or forage fish. English sole consume infaunal invertebrates and so represent the sediment-to-biota contaminant link for contaminants that tend to accumulate in sediments. Adult Pacific herring primarily consume zooplankton and are themselves prey to virtually every large piscivorous species in Puget Sound, and so generally represent the pathway of contaminants to higher level predators including Pacific salmon, seabirds, harbor seals and killer whales.

A significant challenge for long-term toxics monitoring programs is collecting data that are comparable over long time periods either by maintaining consistent analytical methods through time, or by conducting comparison studies as methods change. This includes selection of extraction solvents and extraction methods, and subtle changes in sample handling. In addition, comparisons of contaminant levels among studies can be difficult because differing methods or summation algorithms are often used to estimate total PCBs, PBDEs, or other POP groups. Monitoring programs often rely on subsets of congeners or analytes that are readily measured using low-resolution methods, to avoid the high cost of 


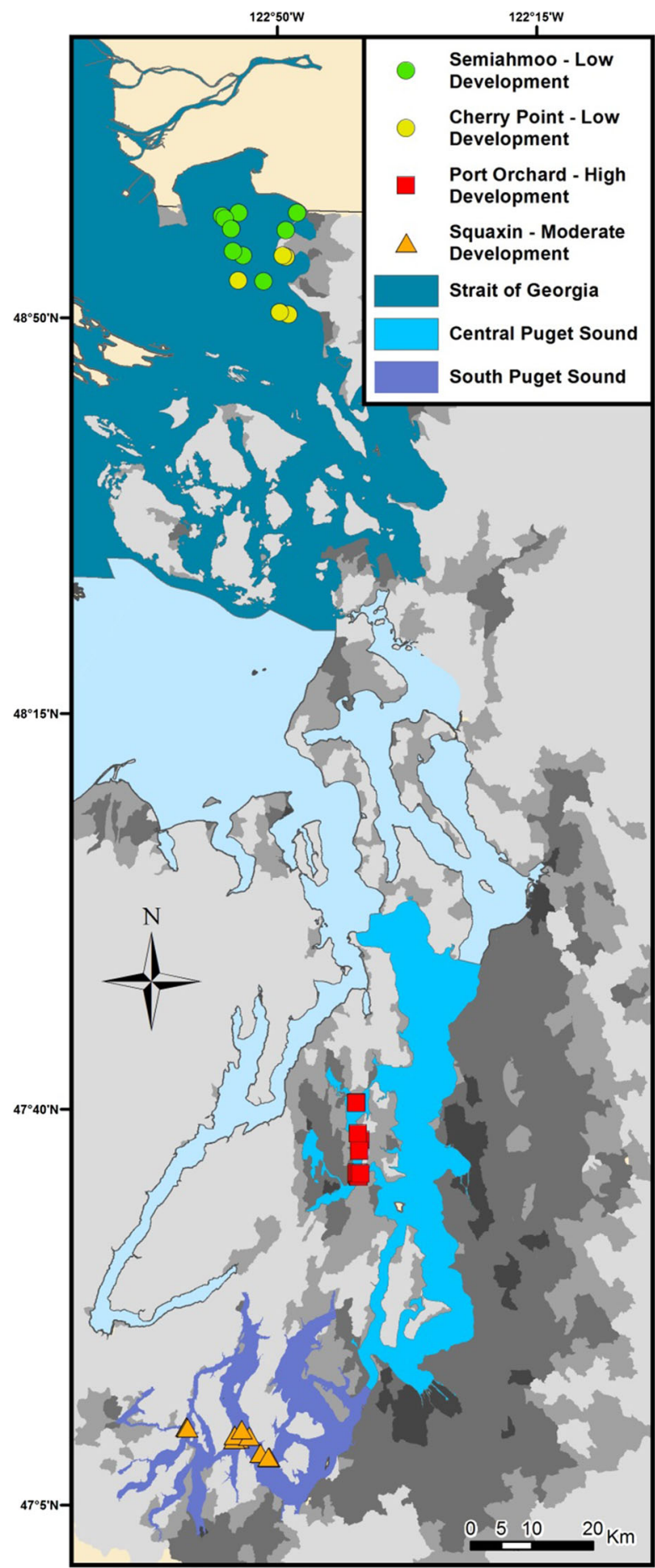

(a) Pacific herring

Fig. 1 Sampling locations for Pacific herring and index sites for English sole. Pacific herring basins classified as high development, moderate development, or low development based on proximity to upland impervious surface. Impervious land-surface shown as greyscale gradations from $<5 \%$ (lightest grey) to $>50 \%$ (darkest grey).

measuring all 209 congeners using more comprehensive analytical methods such as high-resolution gas chromatography/mass spectrometry.

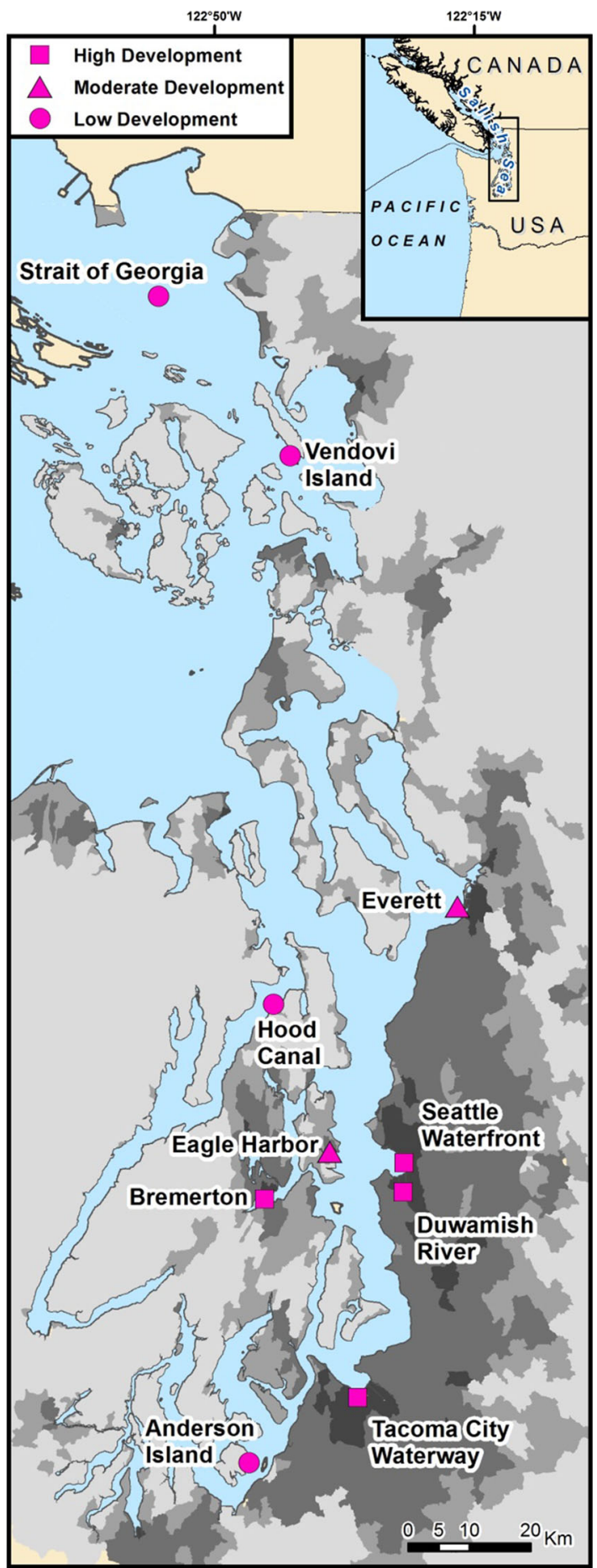

(b) English sole

English sole index sites classified as follows: high development (within $500 \mathrm{~m}$ of land with $>50 \%$ impervious surface), moderate development (within $500 \mathrm{~m}$ of land with $>25 \%$ impervious surface or within $2000 \mathrm{~m}$ of land with $>50 \%$ impervious surface) or low development (more than $2000 \mathrm{~m}$ away from land with $>25 \%$ impervious surface)

In the current study, we report concentrations of PCBs, PBDEs and DDTs in two primary indicator species, English sole and Pacific herring, from Puget Sound, 
Washington over a 16- to 21-year time period. Our objectives were (1) to apply correction factors to POP data to mitigate biases related to changes in analytical methodology and quantitation methods as techniques evolved during the monitoring periods, (2) to evaluate whether contaminant conditions are improving or worsening in Puget Sound, (3) to compare current contaminant conditions for these species for ten index sites (English sole) and three oceanographic basins (Pacific herring) representing a wide range of contamination, (4) to compare PCB summations used in our monitoring program with $\sum \mathrm{ICES}_{7}$, a PCB congener summation method sanctioned by the International Council for the Exploration of the Sea, and used by many European monitoring programs, (5) to compare our POP results with published critical body residues (see, Meador et al. 2011) to infer the likelihood of toxicopathic health effects on fish, and (6) to identify cases where POP body residues in fish were great enough to generate consumption advisories to protect human health.

\section{Methods}

\section{Study Area and Sample Collection}

Study areas for both indicator species were chosen to satisfy a wide range of needs for long-term monitoring of contaminants in Puget Sound's pelagic and benthic food webs (Fig. 1). Three of the most abundant stocks of winterspawning Pacific herring were selected to represent the pelagic food web in three oceanographic basins characterized by a wide range of land-development in their watersheds. The Port Orchard stock was sampled from central Puget Sound, which is characterized by highly developed or urbanized watersheds (termed high-development). The Semiahmoo stock was sampled from the southern Strait of Georgia, which is characterized by rural watersheds with little development, and a relatively direct connection to oceanic waters (termed low-development). The Squaxin stock was sampled from south Puget Sound, which exhibited relatively low land development, however its connection to oceanic waters was through the highly developed central Puget Sound, so its level of development was characterized as moderate. A fourth herring stock, Cherry Point, also occurring in the low-development southern Strait of Georgia was tracked because its unique springtime spawn-timing separates it from the other stocks, and its long history of precipitous decline has made it a priority for protection and recovery. All herring were collected in the winter (January through March) as they aggregated for spawning in predictable locations, except for Cherry Point herring, which were taken in May or June. Fish were captured using gill-nets along shores where spawning activity was occurring, or using midwater trawls in nearby off-shore waters where pre-spawners aggregated. To minimize the effects of reproduction and fish age on POP concentration, only male herring were selected, from sizes that were likely to be 3 -year-old fish. Fifty male herring were sampled from each location and year. Ten composite samples, each containing five male herring were created by homogenizing whole bodies together using a food-grade stainless steel and aluminum grinder.

Ten English sole index sites were selected to represent a wide range of potential contaminant inputs for this benthic species, across the full geographic range of Puget Sound (Fig. 1). Degree of impervious surface in watershed uplands was used as a proxy for land development and also to classify index sites as follows: high development (within $500 \mathrm{~m}$ of land with $>50 \%$ impervious surface), moderate development (within $500 \mathrm{~m}$ of land with $>25 \%$ impervious surface or within $2000 \mathrm{~m}$ of land with $>50 \%$ impervious surface), or low development (more than $2000 \mathrm{~m}$ away from land with $>25 \%$ impervious surface). High development sites were typically close to shore $(<500 \mathrm{~m})$, whereas some moderate- and low-development sites were more than $2000 \mathrm{~m}$ from the shoreline used to classify them. Watershed impervious surface was estimated using the \% imperviousness data layer from the 2006 National Land Cover Database (Fry et al. 2011; Wickham et al. 2013) for closest catchment areas draining into Puget Sound.

Although English sole are known to make long-distance movements for spawning in winter months before homing back to their feeding ground in the spring and summer months (Moser et al. 2013), they are typically sedentary during spring and summer months (Day 1976), where they exhibit small, predictable foraging ranges (O'Neill et al. 2007). Because they are thought to feed little during the winter (Day 1976), their POP tissue burdens likely represent local conditions of their spring/summer habitats. All English sole were captured using a bottom trawl, and skinoff muscle tissue was later resected from either fresh/iced or frozen/thawed specimens. An equal mass of muscle (typically $10 \mathrm{~g}$ ) was resected from each of $60-120$ specimens per site per year and combined randomly to create three or six composite groups of 10-20 fish each. Composited tissues were homogenized using hand-held stainless steel electric mixers.

\section{Chemical Analyses}

Two analytical methods, two extraction methods, and two extraction solvents were used to measure POPs in English sole and Pacific herring samples over the duration of this study. The most recently collected samples were analyzed by gas chromatography/mass spectrometry (GC/MS) and accelerated solvent extraction (ASEx) with methylene 
chloride (MeCl) according to Sloan et al. (2014). Specifications for instruments, supplies and materials used in all GC/MS runs are detailed in Sloan et al. (2004, 2014). Earlier collected samples were analyzed via high-performance liquid chromatography with photodiode array (HPLC/PDA) detection according to Krahn et al. (1994). The HPLC/PDA analytical method was conducted with either manual solvent extraction (MSEx) and equal volumes of pentane and hexane (PenHex), or ASEx using $\mathrm{MeCl}$.

Tissue samples were analyzed using GC/MS with ASEx according to Sloan et al. (2014) from 2005 to 2015 for PCBs and DDTs and from 1994 to 2015 for PBDEs (using a combination of real-time and archived samples). In brief, this method comprised three steps: (1) ASEx of tissue using $\mathrm{MeCl}$, (2) two-step cleanup of the $\mathrm{MeCl}$ extract by silica/aluminum columns and size-exclusion high-performance liquid chromatography (SEC HPLC) to remove lipids and other biogenic compounds, and (3) quantitation of POPs using GC/MS with selected-ion-monitoring (SIM). The ASEx provided an extract that was used for analyte recovery and gravimetric lipid evaluation. Accuracy of the instrument was improved by including chemical ionization filaments (used to increase source temperature), a cool oncolumn injection system in the GC, and a guard column before the analytical column. Point-to-point calibration was used improve data fit over the full range of GC/MS calibration standards (Sloan et al. 2004). Forty-seven PCBs, 11 PBDEs, and 5 DDTs were routinely detected in all samples.

Total PCBs analyzed by GC/MS were estimated using a simple algorithm based on a subset of 17 commonly detected PCB congeners representing homologs containing three to ten chlorine atoms (IUPAC numbers 18, 28, 44, 52, $66,101,105,118,128,138,153,170,180,187,195,206$, and 209) wherein the sum of detected values for these 17 congeners was multiplied by 2 to estimate total PCBs. This algorithm was developed in the context of a US nationwide toxics monitoring program from empirical data (Lauenstein and Cantillo 1993), as a cost-effective way to estimate total PCBs from a small subset of congeners using relatively inexpensive low-resolution analytical techniques. Total PCBs were estimated by Lauenstein and Cantillo (1993) using 18 congeners (those above, plus PCB 8); however, PCB 8 was not quantitated in the current study, so the algorithm employed herein summed only 17 congeners, with the estimation of total PCBs hereafter referred to as $2 \sum_{17}$ PCBs. Although PCB 8 was detected in 30 samples of fish tissue in another study of pelagic Puget Sound fish using high-resolution GC/MS methods (West et al. 2011b), concentrations ranged only from 0.0014 to $0.012 \mathrm{ng} / \mathrm{g}$ wet wt, suggesting that it would be undetectable by the methods used in this study. Lauenstein and Cantillo's (1993)
$2 \sum_{18} \mathrm{PCBs}$ provided excellent agreement with total PCBs estimated from a total chlorination method in their study, and $2 \sum_{17} \mathrm{PCBs}$ in the current study agreed well with total PCBs estimated from the sum of 209 congeners measured by high resolution methods (linear regression of $\sum 209$ congeners by $2 \sum_{17} \mathrm{PCBs}, r^{2}=0.997, p=0.003$, slope coefficient $=0.991$, intercept not significant, $p=0.892$ ) for a subset of five English sole and herring from this study.

To facilitate broader interpretation of our $2 \sum_{17} \mathrm{PCBs}$ results, we also compared them with $\sum \mathrm{ICES}_{7} \mathrm{PCBs}$, a commonly calculated summed PCB estimate in European biota (International Council for the Exploration of the Sea 1987). In a linear regression of 1089 fish and invertebrate samples analyzed by WDFW from 1994 to 2014, the $2 \sum_{17} \mathrm{PCBs}$ were approximately 2.6 times higher than $\sum \mathrm{ICES}_{7}$ PCBs calculated from the same samples (linear regression, $\quad r^{2}=0.998, \quad p<0.0001$, slope coefficient $=2.58$, intercept $=0.61$ ).

Summed PBDEs were calculated as the sum of detected values for the 11 identified PBDE congeners (IUPAC numbers 28, 47, 49, 66, 85, 99, 100, 153, 154, 155, 183), hereafter referred to as $\sum_{11}$ PBDEs, and summed DDTs were calculated as the sum of detected values for five identified DDT compounds ( $o, p$ '-DDD, $p, p$ '-DDD, $p, p$ 'DDE, $o, p$ '-DDT, and $p, p^{\prime}$-DDT), hereafter referred to as $\sum{ }_{5}$ DDTs. In cases where no single PBDE or DDT analyte was detected in a sample for its group, a value of the greatest LOQ for all analytes in a group was substituted for the total. This value was typically less than $1 \mathrm{ng} / \mathrm{g}$ wet wt. At least one PCB congener was detected in every sample.

Although all PBDEs were analyzed by the most current method by combining archived tissues and real-time samples, before 2005 PCBs and DDTs were analyzed using HPLC/PDA detection according to Krahn et al. (1994) (see correction procedure in "Method Performance" section). In addition the method of extraction changed from MSEx using PenHex from 1997 to 2003 (Sloan et al. 2005) to ASEx using MeCl (2003-2005). Briefly, for the HPLC/ PDA, sample extracts were reduced in volume to approximately $1 \mathrm{ml}$ and the POPs were separated from interfering compounds (e.g., lipids and aromatic compounds) on a gravity flow cleanup column that contained neutral, basic, and acidic silica gels eluted with PenHex (1997-2003) or $\mathrm{MeCl}$ (2003-2005). PCB congeners (IUPAC numbers 77, $105,101,110,118,126,128,138,153,156,157,169$, 170/194, 180, and 189) were resolved from five chlorinated pesticides ( $o, p$ '-DDD, $p, p^{\prime}$-DDD, $p, p^{\prime}$-DDE, $o, p$ '-DDT, $p, p$ '-DDT) by HPLC on two Cosmosil PYE analytical columns, connected in series and cooled to $16{ }^{\circ} \mathrm{C}$. Compounds were measured by an ultraviolet (UV) PDA and were identified by comparing their UV spectra (200$310 \mathrm{~nm}$ ) and retention times to those of reference standards in a library. Analyte purity was confirmed by comparing 
spectra within a peak to the apex spectrum. The concentration of total PCBs analyzed by HPLC/PDA was estimated as the sum of the concentrations of the 16 PCBs listed above (based on individual response factors) plus the sum of the concentrations of other unidentified PCBs calculated by summing areas of peaks identified as PCBs and using an average PCB response factor. Summed DDTs were calculated as the sum of detected values of the five DDT isomers. If no DDT isomer was detected in a sample, the greatest LOQ for the five isomers (typically $<0.5 \mathrm{ng} / \mathrm{g}$, wet wt) was substituted as the summed DDT value for that sample.

Lipid concentration was determined gravimetrically in all samples from all years. For PCBs and DDTs from 1997 to 2003, lipids were extracted using MSEx with PenHex and homogenized with a tissue grinder (Sloan et al. 2004). Lipids for PCBs and DDTs from 2003 onward and for all PBDEs (1994-2015) were extracted using ASEx with $\mathrm{MeCl}$ (Sloan et al. 2014).

\section{Method Performance}

Recoveries of analytes from the National Institute of Standards and Technology (NIST) Standard Reference Materials (SRMs) were considered the primary measure of analytical performance for all methods, especially over the long-term, as equipment and supplies can vary through time, even for standardized methods. Additional quality control measures, including sample replication and addition of surrogate standards, were used to identify problematic batches according to Sloan et al. (2004, 2014); however, these metrics typically passed quality control limits and so are not further reported here. A sample of NIST SRM 1974a (blue mussel) was analyzed with each HPLC/PDA sample batch; NIST SRM 1947 (Lake Michigan fish tissue) samples were run with GC/MS batches before 2015 and NIST SRM 1946 (Lake Superior fish tissue) was used after 2015. All batches contained 12-14 field samples. A NIST SRM quality control limit was used to flag poorly analyzed batches for reanalysis; batches were rejected if $\geq 30 \%$ of individual analytes measured in the NIST SRM exceeded $30 \%$ of the $95 \%$ confidence interval range of the published NIST certified concentrations and reanalyzed until they complied with recovery controls.

SRM recovery target concentrations were further calculated for each of the three POP classes by summing the NIST certified or reference values for analytes that were analyzed in field samples. Measuring recovery of SRM analytes through time provided an estimate of variance for method performance, which we calculated as the $95 \%$ confidence interval (CI) for the year factor in a linear regression of the SRM analyte recovery by year (or the CI of the mean analyte \% recovery if the year coefficient was not significant). Significant year coefficients from field sample regressions falling within the $95 \%$ confidence interval from SRM \% recovery regressions were deemed indistinguishable from method variability and censored as not significant as described below.

For the 17 congeners used in $2 \sum_{17} \mathrm{PCB}$ measured by GC/MS, certified values for PCB 66 and 195 were unavailable from NIST, so \% recovery was calculated using a sum of the other 15 congeners from the $2 \sum_{17} \mathrm{PCB}$ list. Ninety-six percent of the resulting $\sum_{15} \mathrm{PCB}$ concentrations recovered from SRM 1947 and SRM 1946 were within $15 \%$ of the NIST certified $95 \%$ confidence interval, indicating a high degree of accuracy. $\sum_{15} \mathrm{PCB}$ recoveries in SRMs from the GC/MS showed no significant timerelated bias, based on a linear regression of SRM \% recovery by year for English sole $(p=0.49)$ and herring $(p=0.68)$. Overall, the $95 \%$ confidence interval for the mean $\sum_{15}$ PCB SRM recovery was only $\pm 2.1 \%$ for English sole and $\pm 1.9 \%$ for herring; accounting for this variability in the \% recovery of the SRM, significant time trend year coefficients (i.e., slopes) from field sample regressions of $2 \sum_{17} \mathrm{PCBs}$ by year within these ranges were considered indistinguishable from analytical variability and subsequently censored as not significant. Eighty-six percent of summed PBDE SRM recoveries were within $15 \%$ of the NIST-certified 95\% confidence interval. PBDE SRM recoveries did not vary significantly with time for English sole and only weakly for herring batches (linear regression of PBDE recovery by time, $p=0.057$, adjusted $r^{2}=0.084$ for English sole; $p=0.012$, adjusted $r^{2}=0.22$ for herring) with slight annual rates of decline of 0.86 and $0.83 \%$. PBDE time trends in field samples falling within the $95 \%$ confidence interval of the PBDE SRM \% recovery regression slope $(-1.7$ to $-0.024 \%$ for English sole and -1.4 to $-0.24 \%$ for herring) were considered indistinguishable from analytical variability, and subsequently censored as not significant. Eighty-nine percent of summed DDT SRM recoveries were within $15 \%$ of the NIST-certified 95\% confidence interval; however, SRM recoveries of DDTs decreased consistently through time (linear regression of summed DDT recovery by year, $p<0.001$, adjusted $r^{2}=0.52$ for English sole; $p<0.001$, adjusted $r^{2}=0.67$ for herring). DDT time trends reported herein for field collected samples were considered indistinguishable from this bias if they fell within the 95\% confidence interval of the slope coefficient from the SRM time regressions $(-2.6$ to $-1.3 \%$ for English sole; -2.9 to $-1.6 \%)$ and subsequently censored as not significant.

SRM recoveries for PCBs analyzed by HPLC/PDA were lower than the GC/MS method; $16 \%$ of PCBs, calculated as a sum of 8 congeners in common between the field samples and SRM certified values, were within $15 \%$ of the NISTcertified 95\% confidence interval. Recoveries of DDTs 
from SRMs analyzed by the HPLC/PDA were hampered by the presence of unidentified interfering compounds, and so SRM recoveries were unusable for that analyte group. PBDEs were not measured by the HPLC/PDA method. However, DDT and PCB results from HPLC/PDA analyzed field samples were corrected using a robust sampleto-sample comparison described below. This method corrected HPLC/PDA results to GC/MS standards, essentially precluding the need to evaluate or correct for SRM recoveries from the HPLC/PDA results. Moreover, the SRM recoveries for PCBs and DDTs appeared to be consistent through time for each species, based on a visual inspection of the SRM recoveries; low sample size prevented computing valid regression models for the HPLC/ PDA methods.

\section{Method-Bias Corrections for Time Trends}

To correct for bias in estimated total PCB estimates associated with analytical method changes, 76 samples that had been analyzed by the older methods were reanalyzed using the GC/MS with ASEx described above: 14 samples by the HPLC/PDA method with MSEx and 62 samples by the HPLC/PDA with ASEx. Correction factors were calculated by regressing $2 \sum_{17} \mathrm{PCBs}$ from the GC/MS with ASEx method against estimated total PCBs calculated from each of the HPLC/PDA groups in the same samples. In both cases, the HPLC/PDA methods underestimated $2 \sum_{17}$ PCBs; by approximately 33\% for the MSEx group (linear regression of $2 \sum_{17} \mathrm{PCBs}$ by total $\mathrm{PCBs}, r^{2}=0.90$, $p<0.001$, slope coefficient $=1.331$, intercept not significant, $p=0.97)$, and $27 \%$ for the ASEx group $\left(r^{2}=0.94\right.$, $p<0.001$, slope coefficient $=1.267$, intercept not significant, $p=0.83$ ).

The same five DDT analytes were measured across both analytical and extraction methods, precluding a need for method-corrections based on summation of differing chemicals in the group. However, a comparison of $\sum_{5}$ DDTs across the methods revealed a difference in quantitation of individual DDTs related to the solvent extraction method. $\sum_{5}$ DDTs measured by the HPLC/PDA method with ASEx were similar to results from the GC/MS with ASEx and therefore required no adjustment (linear regression of paired $\sum_{5}$ DDTs by both methods; $r^{2}=0.95$, $p<0.001$, slope coefficient $=0.95$, intercept not significant, $p=0.77$ ); however, $\sum_{5}$ DDTs measured by HPLC/ PDA with MSEx were approximately $45 \%$ lower than the GC/MS method (linear regression; $r^{2}=0.95, p<0.001$, slope coefficient $=1.45$, intercept not significant, $p=0.68$ ). Hence, $\sum_{5}$ DDTs were adjusted upwards according to this latter regression model, for samples that were only analyzed by the HPLC/PDA and MSEx.
Beginning in 2005, PBDEs were always measured in both species of fish by the GC/MS method described above with ASEx, and all PBDE in prior years were determined from archived tissue samples. Thus, no adjustments were made for any PBDE data.

\section{Data Analysis}

For evaluation of time trends, we used multiple linear regressions of $2 \sum_{17}$ PCBs, $\sum_{11}$ PBDEs, and $\sum_{5}$ DDTs over time, with year as the independent variable, to evaluate whether observed time trends in POPs were statistically significant. The contribution of biological covariates in explaining POP variability also was evaluated. Compositemean fish length (MCL) was used as a proxy for fish age, which can be considered an estimate of total potential exposure time to contamination. Because the POPs measured in this study are considered lipophilic, total nonvolatile extractibles (percent lipids) were included to help control for variability in that measure. The sex ratio (proportion of male fish) was included to help control for potential differences related to loss of POPs in reproducing female fish. Automatic stepwise regression models were run using SYSTAT (2007), for each log-transformed POP total in separate runs, with the covariates listed above and their interactions. Although some interaction terms were occasionally significant, all interaction terms explained little POP variation (usually less than 3\%), and including them did not appreciably change results. Hence, for simplicity they were omitted from the final regression models. Geometric mean POP concentrations and confidence intervals were adjusted for significant covariate terms by predicting the POP concentration through time from the multiple linear regression models, using the grand mean value for MCL, lipids, or sex ratio, when they were included in the final model. Partial coefficients of determination $\left(r^{2}\right)$ were calculated at each step of the forward stepwise multiple linear regression to estimate the contribution of each significant covariate in explaining POP concentration in the final model. A significant $(p>0.05)$ year coefficient in the final model was accepted as evidence for a significant time trend; however, as an additional guard against overinterpreting weak trends, year coefficients with $r^{2}<0.10$ (i.e., time explaining $<10 \%$ of POP variability) were censored as trivial (and models presented as dashed lines in graphs).

To evaluate the most current status of POPs in English sole and herring, we used analysis of variance (ANOVA) to test the significance of observed log-transformed POP differences between the ten English sole index sites collected in 2015 and between the four herring stocks collected in 2014. Although lipids, fish size, and sex ratio were tested as ANOVA covariates, none was a significant 
contributor in explaining POP variation, so POPs were not adjusted by these factors for the current status comparison.

\section{Results}

Time series data for herring comprised 12 sampling years spanning a 16-year period from 1999 to 2014 for two stocks (Port Orchard and Squaxin), 9 years over the same period for Semiahmoo and 6 years of sampling over a 21-year period for Cherry Point (Table 1). The time series for English sole covered 9 to 12 sampling years over an 18or 19-year span for all sites except the Duwamish River, which was sampled in 1997 and then not again until 2007-2015 (Table 1). The most recent years for both species were analyzed below to represent current status.

Of the three POP classes reported in our study, $2 \sum_{17}$ PCBs dominated in concentration for both fish species, followed by $\sum_{11} \mathrm{PBDE}$ and $\sum_{5} \mathrm{DDT}$. The $2 \sum_{17} \mathrm{PCB}$ concentrations from the most current sampling were 3-6 times greater than $\sum_{11} \mathrm{PBDE}$ and 3-16 times greater than $\sum_{5}$ DDTs in 2014 Pacific herring (Fig. 2) and 10-63 times greater than $\sum_{11} \mathrm{PBDE}$ and 10-67 times greater than $\sum_{5}$ DDTs in 2015 English sole (Fig. 3). Percent lipids in whole body herring ranged from 2.5 to $10 \%$, with highest values determined in herring from Squaxin (4.4-10\%) and lowest in those from Cherry Point (2.5-4.2\%). Size of the male herring ranged relatively narrowly (by study design) from 143 to $181 \mathrm{~mm}$ SL (Table 1). Lipid values for English sole muscle were consistently low across all years and all sites, ranging from 0.16 to $0.88 \%$ (Table 1). Size of English sole (as mean composite length) ranged from 253 to $380 \mathrm{~mm}$ TL, and the proportion of male fish (sex ratio) in the composites ranged widely from 1 to $92 \%$.

\section{Pacific Herring Current Status}

PCB concentrations in male Pacific herring in 2014 were highest in fish from the Squaxin stock $(210 \mathrm{ng} / \mathrm{g}$, moderately developed basin) and Port Orchard stock (190 ng/g, highly developed basin), followed by $46 \mathrm{ng} / \mathrm{g}$ in fish from Cherry Point and $18 \mathrm{ng} / \mathrm{g}$ from Semiahmoo stocks, both from a basin characterized by low-development (Table 1; Fig. 2). Levels of $\sum_{11}$ PBDEs and $\sum_{5}$ DDTs showed a similar pattern, with decreasing concentrations from Squaxin to Port Orchard to Cherry Point to Semiahmoo. Fish length and lipid covariates (or their interactions) were sometimes significant in the ANCOVA models comparing locations in the current status analysis; however, they were dropped from the final model, because they consistently accounted for a minor amount $(<3 \%)$ to the variability in concentration in any of the POPs. Geometric means and confidence intervals (shown in Fig. 2) were not adjusted for any covariates.

\section{Pacific Herring Time Trends}

Concentrations of $2 \sum_{17} \mathrm{PCBs}$ remained unchanged over the course of the study in herring stocks from Port Orchard (highly developed basin) and Squaxin (moderately developed basin). The year coefficient for $2 \sum_{17} \mathrm{PCBs}$ in Port Orchard herring was censored, because it was both indistinguishable from SRM variability and its partial correlation coefficient was $<0.10$; hence a $2 \sum_{17} \mathrm{PCBs}$ rate was reported as not significant for that stock (Table 2). Year was not significant for Squaxin in the multiple linear regression $(p>0.05)$. Even though year was not a significant predictor of $2 \sum_{17} \mathrm{PCBs}$ for these two stocks, a predicted (dashed) line was calculated (shown in Fig. 4 for reference). Levels of $2 \sum_{17} \mathrm{PCBs}$ in both herring stocks from the northern, low-development basin (Semiahmoo and Cherry Point stocks) declined significantly, with annual rates of 4.0 and $2.3 \%$ (Fig. 4; Table 2). MCL and lipids were either not significant, or weakly to moderately predictive in all stocks, with partial correlation coefficients ranging from 0.02 to 0.44 . $2 \sum_{17} \mathrm{PCBs}$ in all predicted lines calculated for Fig. 4 were adjusted for significant covariates.

The $\sum_{11}$ PBDE levels declined in all herring stocks from all basins, with annual reductions ranging from 4.3 to $8.1 \%$. Fish size (MCL) contributed significantly to explaining PBDE variation with partial $r^{2}$ ranging from 0.16 to 0.41$)$, and lipids were weakly predictive for Squaxin $\left(r^{2}=0.02, p<0.05\right)$ or insignificant $(p>0.05)$ for the other three stocks (Table 2). Final PBDE regression models were moderately predictive, with $r^{2}$ ranging from 0.52 to 0.71 ; predicted lines were adjusted using grand mean values for significant coefficients (Fig. 4).

As with $\sum_{11}$ PBDEs, $\sum{ }_{5}$ DDTs declined in all herring stocks, with rates ranging from $5.6 \%$ (Port Orchard) in the highly developed basin, $4.2 \%$ from Squaxin in the moderately developed basin, to 5.8 and $7.0 \%$ in the two stocks from the low-development basin (Cherry Point and Semiahmoo; Fig. 4). Final DDT models were moderately to strongly predictive, with $r^{2}$ ranging from 0.54 to 0.87 (Table 2). Along with year, MCL was a significant partial predictor for all four stocks, albeit most strongly for Squaxin herring, and grand mean values for significant covariates were used to adjust the predicted lines in Fig. 4.

\section{English Sole Current Status}

Concentrations of $2 \sum_{17} \mathrm{PCBs}$ were generally highest in English sole at highly developed sites; in the most current sampling year (2015) arithmetic mean concentrations 
Table 1 Arithmetic mean concentration (ng/g in wet weight and lipid weight) of PCBs, PBDEs, and DDTs and biological metrics for composite samples of Pacific herring (Clupea pallasii; $n=10$ fish per composite) and English sole (Parophrys vetulus; $n=10-20$ fish per composite) for all years sampled. Contaminant means not corrected for biological covariates. Herring represented by four stocks in three oceanographic basins and sole from ten index sites. na indicates not applicable; nfs indicates no fish sampled. Mean composite length (MCL) is the mean standard length in $\mathrm{mm}$ of all fish in each sample

\begin{tabular}{|c|c|c|c|c|c|c|c|c|c|c|c|}
\hline & \multirow[t]{2}{*}{ Sex ratio ( $\%$ males) } & \multirow[t]{2}{*}{ MCL (mm) } & \multirow[t]{2}{*}{ Lipids (\%) } & \multicolumn{2}{|c|}{$2 \sum_{17} \mathrm{PCBs}$} & \multicolumn{2}{|c|}{$\mathrm{ICES}_{7} \mathrm{PCBs}$} & \multicolumn{2}{|c|}{$\sum_{11}$ PBDEs } & \multicolumn{2}{|c|}{$\sum_{5} \mathrm{DDTs}$} \\
\hline & & & & Wet & Lipid & Wet & Lipid & Wet & Lipid & Wet & Lipid \\
\hline \multicolumn{12}{|c|}{ Cherry Point herring } \\
\hline 1994 & na & 162 & 3.1 & 89 & 2900 & 34 & 1100 & 30 & 980 & 19 & 600 \\
\hline 1999 & na & 176 & 3.3 & 58 & 1800 & 22 & 680 & $\mathrm{nfs}$ & nfs & 19 & 530 \\
\hline 2001 & na & 172 & 2.7 & 61 & 2300 & 23 & 900 & 24 & 900 & 18 & 630 \\
\hline 2007 & na & 171 & 2.5 & 56 & 2400 & 21 & 900 & 23 & 970 & 12 & 480 \\
\hline 2012 & na & 171 & 4.2 & 50 & 1200 & 19 & 480 & 17 & 400 & 7.1 & 170 \\
\hline 2014 & na & 159 & 3.0 & 46 & 1500 & 18 & 580 & 13 & 410 & 6.7 & 220 \\
\hline \multicolumn{12}{|c|}{ Port Orchard herring } \\
\hline 1999 & na & 170 & 6.5 & 200 & 3100 & 77 & 1200 & $\mathrm{nfs}$ & $\mathrm{nfs}$ & 36 & 500 \\
\hline 2000 & na & 169 & 5.1 & 230 & 4700 & 87 & 1800 & $\mathrm{nfs}$ & $\mathrm{nfs}$ & 34 & 620 \\
\hline 2001 & na & 169 & 5.6 & 230 & 4200 & 90 & 1600 & 96 & 1600 & 27 & 440 \\
\hline 2002 & na & 169 & 5.2 & 240 & 4700 & 91 & 1800 & 70 & 1500 & 25 & 410 \\
\hline 2003 & na & 172 & 5.6 & 250 & 4700 & 96 & 1800 & 96 & 2100 & 23 & 350 \\
\hline 2004 & na & 166 & 5.5 & 160 & 3000 & 63 & 1200 & 48 & 910 & 16 & 250 \\
\hline 2006 & na & 171 & 8.3 & 210 & 2600 & 81 & 1000 & 47 & 580 & 18 & 230 \\
\hline 2007 & na & 164 & 6.7 & 220 & 3300 & 83 & 1300 & 59 & 900 & 19 & 300 \\
\hline 2008 & na & 167 & 4.8 & 180 & 3800 & 68 & 1500 & 39 & 890 & 16 & 350 \\
\hline 2010 & na & 157 & 4.9 & 160 & 3400 & 62 & 1300 & 25 & 530 & 13 & 280 \\
\hline 2012 & na & 181 & 5.6 & 220 & 4100 & 86 & 1600 & 53 & 960 & 19 & 350 \\
\hline 2014 & na & 164 & 5.5 & 190 & 3400 & 72 & 1300 & 30 & 550 & 12 & 220 \\
\hline \multicolumn{12}{|c|}{ Semiahmoo herring } \\
\hline 1999 & na & 175 & 5.1 & 58 & 1100 & 22 & 430 & $\mathrm{nfs}$ & $\mathrm{nfs}$ & 22 & 400 \\
\hline 2000 & na & 168 & 4.9 & 55 & 1200 & 21 & 450 & nfs & nfs & 23 & 440 \\
\hline 2001 & na & 171 & 3.8 & 53 & 1500 & 20 & 570 & 29 & 850 & 19 & 460 \\
\hline 2002 & na & 166 & 4.2 & 38 & 940 & 15 & 360 & 19 & 470 & 17 & 350 \\
\hline 2003 & na & 171 & 4.8 & 43 & 920 & 16 & 350 & 25 & 580 & 14 & 240 \\
\hline 2004 & na & 171 & 3.5 & 39 & 1100 & 15 & 440 & 17 & 520 & 15 & 430 \\
\hline 2006 & na & 158 & 4.8 & 31 & 660 & 12 & 250 & 9.3 & 200 & 11 & 230 \\
\hline 2012 & na & 176 & 4.2 & 44 & 1100 & 17 & 420 & 18 & 420 & 12 & 280 \\
\hline 2014 & na & 162 & 3.2 & 18 & 550 & 6.8 & 210 & 5.5 & 170 & 5.5 & 180 \\
\hline \multicolumn{12}{|c|}{ Squaxin herring } \\
\hline 1999 & na & 165 & 9.5 & 240 & 2800 & 91 & 1100 & nfs & $\mathrm{nfs}$ & 38 & 400 \\
\hline 2000 & na & 157 & 7.7 & 170 & 2200 & 65 & 850 & $\mathrm{nfs}$ & $\mathrm{nfs}$ & 25 & 290 \\
\hline 2001 & na & 156 & 6.8 & 170 & 2600 & 67 & 990 & 56 & 890 & 23 & 300 \\
\hline 2002 & na & 163 & 6.1 & 280 & 4600 & 110 & 1800 & 88 & 1500 & 37 & 520 \\
\hline 2003 & na & 166 & 6.8 & 240 & 3700 & 93 & 1400 & 120 & 1800 & 29 & 370 \\
\hline 2004 & na & 160 & 6.3 & 170 & 2700 & 64 & 1000 & 71 & 1200 & 19 & 250 \\
\hline 2006 & na & 160 & 10 & 180 & 1800 & 70 & 690 & 58 & 580 & 18 & 170 \\
\hline 2007 & na & 162 & 8.9 & 170 & 1900 & 64 & 720 & 45 & 500 & 17 & 200 \\
\hline 2008 & na & 153 & 6.7 & 160 & 2500 & 63 & 960 & 41 & 620 & 17 & 260 \\
\hline 2010 & na & 143 & 5.2 & 130 & 2400 & 48 & 940 & 29 & 560 & 13 & 240 \\
\hline 2012 & na & 166 & 8.5 & 250 & 2900 & 94 & 1100 & 60 & 710 & 23 & 270 \\
\hline 2014 & na & 163 & 4.4 & 210 & 4800 & 81 & 1800 & 44 & 1000 & 17 & 410 \\
\hline
\end{tabular}


Table 1 continued

\begin{tabular}{|c|c|c|c|c|c|c|c|c|c|c|c|}
\hline & \multirow[t]{2}{*}{ Sex ratio ( $\%$ males) } & \multirow[t]{2}{*}{ MCL (mm) } & \multirow[t]{2}{*}{ Lipids (\%) } & \multicolumn{2}{|c|}{$2 \sum_{17} \mathrm{PCBs}$} & \multicolumn{2}{|c|}{$\mathrm{ICES}_{7} \mathrm{PCBs}$} & \multicolumn{2}{|c|}{$\sum_{11}$ PBDEs } & \multicolumn{2}{|c|}{$\sum{ }_{5} \mathrm{DDTs}$} \\
\hline & & & & Wet & Lipid & Wet & Lipid & Wet & Lipid & Wet & Lipid \\
\hline \multicolumn{12}{|c|}{ Tacoma City Waterway sole } \\
\hline 1997 & 43 & 300 & 0.27 & 22 & 8400 & 8.5 & 3200 & $\mathrm{nfs}$ & $\mathrm{nfs}$ & 0.9 & 420 \\
\hline 1998 & 38 & 278 & 0.36 & 32 & 9300 & 12 & 3600 & nfs & nfs & 0.6 & 190 \\
\hline 1999 & 55 & 255 & 0.41 & 60 & 15,000 & 23 & 5700 & $\mathrm{nfs}$ & $\mathrm{nfs}$ & 4.1 & 1100 \\
\hline 2000 & 50 & 278 & 0.49 & 47 & 9600 & 18 & 3700 & nfs & $\mathrm{nfs}$ & 2.9 & 620 \\
\hline 2001 & 55 & 279 & 0.59 & 98 & 17,000 & 38 & 6400 & nfs & $\mathrm{nfs}$ & 9.0 & 1600 \\
\hline 2003 & 80 & 263 & 0.58 & 200 & 35,000 & 77 & 13,000 & $\mathrm{nfs}$ & $\mathrm{nfs}$ & 8.6 & 1500 \\
\hline 2005 & 61 & 261 & 0.40 & 96 & 24,000 & 37 & 9300 & 12 & 3000 & 6.5 & 1600 \\
\hline 2007 & 48 & 258 & 0.23 & 52 & 23,000 & 20 & 9000 & 3.2 & 1400 & 2.1 & 940 \\
\hline 2009 & 63 & 263 & 0.16 & 110 & 69,000 & 44 & 27,000 & 7.7 & 4700 & 5.2 & 3100 \\
\hline 2011 & 50 & 278 & 0.27 & 110 & 40,000 & 41 & 15,000 & 9.3 & 3400 & 3.6 & 1300 \\
\hline 2013 & 59 & 253 & 0.39 & 95 & 25,000 & 36 & 9700 & 7.5 & 2100 & 3.7 & 990 \\
\hline 2015 & 54 & 261 & 0.28 & 99 & 35,000 & 38 & 14,000 & 6.0 & 2200 & 3.1 & 1100 \\
\hline \multicolumn{12}{|c|}{ Duwamish River sole } \\
\hline 1997 & 58 & 285 & 0.35 & 123 & 35,000 & 47 & 13,000 & $\mathrm{nfs}$ & nfs & 4.2 & 1300 \\
\hline 2007 & 57 & 274 & 0.50 & 290 & 57,000 & 110 & 22,000 & 3.9 & 780 & 5.9 & 1200 \\
\hline 2009 & 48 & 268 & 0.23 & 310 & 141,000 & 120 & 54,000 & 4.3 & 2000 & 6.1 & 2700 \\
\hline 2011 & 36 & 260 & 0.44 & 270 & 62,000 & 110 & 24,000 & 6.4 & 1500 & 4.9 & 1100 \\
\hline 2013 & 44 & 270 & 0.43 & 280 & 65,000 & 110 & 25,000 & 6.9 & 1600 & 4.7 & 1100 \\
\hline 2015 & 47 & 274 & 0.34 & 270 & 81,000 & 100 & 31,000 & 4.3 & 1300 & 4.0 & 1200 \\
\hline \multicolumn{12}{|c|}{ Eagle Harbor sole } \\
\hline 1998 & 43 & 283 & 0.36 & 22 & 6100 & 8.5 & 2400 & $\mathrm{nfs}$ & nfs & 0.2 & 75 \\
\hline 1999 & 30 & 283 & 0.37 & 27 & 7300 & 10 & 2800 & nfs & $\mathrm{nfs}$ & 1.9 & 580 \\
\hline 2000 & 35 & 287 & 0.51 & 28 & 5500 & 10 & 2100 & nfs & $\mathrm{nfs}$ & 1.6 & 330 \\
\hline 2001 & 60 & 279 & 0.52 & 33 & 6300 & 12 & 2400 & $\mathrm{nfs}$ & nfs & 2.3 & 460 \\
\hline 2007 & 36 & 277 & 0.43 & 28 & 6400 & 10 & 2500 & 1.2 & 270 & 0.9 & 200 \\
\hline 2009 & 22 & 275 & 0.40 & 33 & 8300 & 12 & 3200 & 0.63 & 160 & 0.9 & 210 \\
\hline 2011 & 35 & 272 & 0.28 & 78 & 27,000 & 30 & 11,000 & 5.0 & 1700 & 1.8 & 630 \\
\hline 2013 & 26 & 279 & 0.42 & 47 & 11,000 & 18 & 4400 & 1.8 & 450 & 1.1 & 260 \\
\hline 2015 & 26 & 290 & 0.37 & 29 & 8100 & 11 & 3100 & 1.0 & 290 & 0.6 & 180 \\
\hline \multicolumn{12}{|c|}{ Seattle Waterfront sole } \\
\hline 1997 & 55 & 290 & 0.46 & 70 & 14,000 & 27 & 5200 & $\mathrm{nfs}$ & $\mathrm{nfs}$ & 3.4 & 710 \\
\hline 1998 & 57 & 259 & 0.34 & 59 & 18,000 & 23 & 6800 & $\mathrm{nfs}$ & $\mathrm{nfs}$ & 0.3 & 87 \\
\hline 1999 & 73 & 275 & 0.52 & 36 & 7300 & 14 & 2800 & $\mathrm{nfs}$ & $\mathrm{nfs}$ & 2.6 & 530 \\
\hline 2000 & 52 & 307 & 0.66 & 26 & 3900 & 10 & 1500 & $\mathrm{nfs}$ & nfs & 2.2 & 330 \\
\hline 2001 & 83 & 285 & 0.67 & 57 & 9000 & 22 & 3400 & $\mathrm{nfs}$ & nfs & 3.5 & 570 \\
\hline 2003 & 73 & 293 & 0.88 & 89 & 10,000 & 34 & 4000 & $\mathrm{nfs}$ & nfs & 4.3 & 490 \\
\hline 2005 & 87 & 280 & 0.69 & 45 & 6500 & 17 & 2500 & 5.8 & 850 & 2.0 & 350 \\
\hline 2007 & 92 & 261 & 0.35 & 92 & 27,000 & 35 & 10,000 & 7.5 & 2200 & 2.9 & 830 \\
\hline 2009 & 88 & 258 & 0.43 & 50 & 12,000 & 19 & 4600 & 3.4 & 830 & 1.5 & 370 \\
\hline 2011 & 82 & 266 & 0.45 & 100 & 35,000 & 40 & 14,000 & 6.8 & 2100 & 2.4 & 770 \\
\hline 2013 & 86 & 269 & 0.80 & 77 & 9900 & 30 & 3800 & 3.2 & 400 & 1.7 & 220 \\
\hline 2015 & 63 & 271 & 0.53 & 160 & 31,000 & 61 & 12,000 & 4.5 & 910 & 3.0 & 600 \\
\hline \multicolumn{12}{|c|}{ Hood Canal sole } \\
\hline 1997 & 22 & 287 & 0.32 & 2.2 & 690 & 0.9 & 260 & $\mathrm{nfs}$ & nfs & 0.3 & 120 \\
\hline 1998 & 12 & 294 & 0.57 & 2.0 & 340 & 0.8 & 130 & 0.70 & 120 & 0.6 & 120 \\
\hline 1999 & 32 & 274 & 0.21 & 3.2 & 1600 & 1.2 & 600 & $\mathrm{nfs}$ & $\mathrm{nfs}$ & 0.7 & 540 \\
\hline
\end{tabular}


Table 1 continued

\begin{tabular}{|c|c|c|c|c|c|c|c|c|c|c|c|}
\hline & \multirow[t]{2}{*}{ Sex ratio ( $\%$ males) } & \multirow[t]{2}{*}{ MCL (mm) } & \multirow[t]{2}{*}{ Lipids (\%) } & \multicolumn{2}{|c|}{$2 \sum_{17} \mathrm{PCBs}$} & \multicolumn{2}{|c|}{$\mathrm{ICES}_{7} \mathrm{PCBs}$} & \multicolumn{2}{|c|}{$\sum_{11}$ PBDEs } & \multicolumn{2}{|c|}{$\sum_{5} \mathrm{DDTs}$} \\
\hline & & & & Wet & Lipid & Wet & Lipid & Wet & Lipid & Wet & Lipid \\
\hline 2000 & 12 & 276 & 0.45 & 3.2 & 710 & 1.2 & 270 & $\mathrm{nfs}$ & $\mathrm{nfs}$ & 0.4 & 110 \\
\hline 2001 & 30 & 291 & 0.73 & 6.7 & 970 & 2.6 & 370 & $\mathrm{nfs}$ & $\mathrm{nfs}$ & 1.0 & 140 \\
\hline 2003 & 58 & 279 & 0.65 & 14 & 2200 & 5.3 & 840 & 1.1 & 170 & 1.7 & 290 \\
\hline 2005 & 40 & 277 & 0.41 & 5.3 & 1300 & 2.0 & 510 & 0.54 & 130 & 0.6 & 160 \\
\hline 2007 & 31 & 275 & 0.40 & 4.5 & 1300 & 1.7 & 480 & 0.68 & 160 & 0.5 & 140 \\
\hline 2009 & 38 & 296 & 0.54 & 4.6 & 890 & 1.8 & 340 & 0.51 & 100 & 0.4 & 72 \\
\hline 2011 & 38 & 262 & 0.43 & 4.2 & 980 & 1.6 & 380 & 0.36 & 86 & 0.3 & 60 \\
\hline 2013 & 63 & 274 & 0.43 & 7.2 & 1700 & 2.8 & 660 & 0.64 & 150 & 0.6 & 150 \\
\hline 2015 & 42 & 268 & 0.39 & 9.8 & 2400 & 3.8 & 940 & 0.46 & 120 & 0.5 & 130 \\
\hline \multicolumn{12}{|c|}{ Anderson Island sole } \\
\hline 1997 & 40 & 272 & 0.33 & 7.8 & 2400 & 3.0 & 930 & $\mathrm{nfs}$ & $\mathrm{nfs}$ & 0.7 & 260 \\
\hline 1998 & 32 & 268 & 0.35 & 9.8 & 3000 & 3.8 & 1100 & $\mathrm{nfs}$ & $\mathrm{nfs}$ & 0.4 & 120 \\
\hline 1999 & 25 & 265 & 0.27 & 9.3 & 3400 & 3.6 & 1300 & $\mathrm{nfs}$ & $\mathrm{nfs}$ & 1.1 & 510 \\
\hline 2000 & 15 & 254 & 0.45 & 9.6 & 2200 & 3.7 & 830 & $\mathrm{nfs}$ & $\mathrm{nfs}$ & 0.7 & 160 \\
\hline 2001 & 15 & 282 & 0.50 & 13 & 2600 & 5.0 & 1000 & $\mathrm{nfs}$ & $\mathrm{nfs}$ & 1.2 & 250 \\
\hline 2003 & 10 & 268 & 0.51 & 24 & 4900 & 9.3 & 1900 & $\mathrm{nfs}$ & $\mathrm{nfs}$ & 1.4 & 300 \\
\hline 2005 & 14 & 276 & 0.32 & 16 & 4900 & 6.1 & 1900 & 1.5 & 450 & 0.8 & 250 \\
\hline 2007 & 5 & 280 & 0.33 & 12 & 3700 & 4.5 & 1400 & 0.66 & 210 & 0.5 & 150 \\
\hline 2009 & 8 & 272 & 0.22 & 15 & 7300 & 5.9 & 2800 & 1.0 & 490 & 0.7 & 320 \\
\hline 2011 & 10 & 263 & 0.39 & 13 & 3400 & 5.0 & 1300 & 2.0 & 510 & 0.4 & 110 \\
\hline 2013 & 8 & 267 & 0.37 & 19 & 5000 & 7.1 & 1900 & 2.1 & 570 & 0.7 & 190 \\
\hline 2015 & 5 & 262 & 0.32 & 20 & 6900 & 7.8 & 2700 & 1.3 & 460 & 0.6 & 220 \\
\hline \multicolumn{12}{|c|}{ Everett sole } \\
\hline 1997 & 28 & 291 & 0.24 & 15 & 5500 & 3.8 & 2100 & $\mathrm{nfs}$ & $\mathrm{nfs}$ & 2.0 & 900 \\
\hline 1998 & 28 & 253 & 0.28 & 5.1 & 1800 & 1.9 & 690 & $\mathrm{nfs}$ & $\mathrm{nfs}$ & 0.6 & 290 \\
\hline 1999 & 28 & 264 & 0.29 & 7.9 & 3100 & 3.0 & 1200 & $\mathrm{nfs}$ & $\mathrm{nfs}$ & 0.6 & 350 \\
\hline 2000 & 38 & 275 & 0.44 & 9.3 & 2100 & 3.6 & 810 & $\mathrm{nfs}$ & $\mathrm{nfs}$ & 0.9 & 210 \\
\hline 2001 & 18 & 278 & 0.51 & 23 & 4600 & 8.9 & 1800 & $\mathrm{nfs}$ & $\mathrm{nfs}$ & 2.2 & 460 \\
\hline 2003 & 18 & 274 & 0.58 & 18 & 3200 & 7.1 & 1200 & $\mathrm{nfs}$ & $\mathrm{nfs}$ & 1.0 & 180 \\
\hline 2005 & 19 & 290 & 0.40 & 21 & 5200 & 8.0 & 2000 & 1.6 & 380 & 1.0 & 260 \\
\hline 2007 & 26 & 270 & 0.43 & 22 & 5000 & 8.3 & 1900 & 1.9 & 430 & 0.7 & 160 \\
\hline 2009 & 18 & 273 & 0.27 & 17 & 6500 & 6.7 & 2500 & 0.86 & 320 & 0.6 & 240 \\
\hline 2011 & 25 & 274 & 0.31 & 32 & 10,000 & 12 & 3900 & 3.9 & 1300 & 1.0 & 320 \\
\hline 2013 & 14 & 275 & 0.35 & 22 & 6400 & 8.6 & 2400 & 2.3 & 660 & 0.7 & 210 \\
\hline 2015 & 20 & 276 & 0.34 & 24 & 7100 & 9.0 & 2700 & 1.6 & 470 & 0.7 & 200 \\
\hline \multicolumn{12}{|c|}{ Bremerton sole } \\
\hline 1997 & 35 & 350 & 0.38 & 57 & 16,000 & 21 & 6000 & $\mathrm{nfs}$ & nfs & 1.6 & 530 \\
\hline 1998 & 32 & 327 & 0.46 & 130 & 28,000 & 51 & 11,000 & 4.8 & 1000 & 2.6 & 590 \\
\hline 1999 & 40 & 320 & 0.46 & 75 & 17,000 & 29 & 6400 & $\mathrm{nfs}$ & $\mathrm{nfs}$ & 1.8 & 410 \\
\hline 2000 & 15 & 343 & 0.63 & 87 & 14,000 & 34 & 5300 & $\mathrm{nfs}$ & $\mathrm{nfs}$ & 2.1 & 330 \\
\hline 2001 & 52 & 306 & 0.54 & 160 & 32,000 & 63 & 12,000 & $\mathrm{nfs}$ & $\mathrm{nfs}$ & 4.2 & 860 \\
\hline 2003 & 38 & 325 & 0.60 & 170 & 28,000 & 65 & 11,000 & 6.5 & 1100 & 3.5 & 620 \\
\hline 2005 & 22 & 319 & 0.53 & 75 & 14,000 & 29 & 5400 & 1.8 & 330 & 1.6 & 300 \\
\hline 2007 & 23 & 306 & 0.65 & 76 & 12,000 & 29 & 4500 & 1.4 & 220 & 1.2 & 190 \\
\hline 2009 & 26 & 311 & 0.40 & 59 & 15,000 & 23 & 5700 & 1.3 & 340 & 1.3 & 340 \\
\hline 2011 & 13 & 354 & 0.32 & 130 & 42,000 & 49 & 16,000 & 4.5 & 1500 & 1.8 & 600 \\
\hline 2013 & 27 & 327 & 0.49 & 70 & 14,000 & 27 & 5500 & 1.8 & 370 & 1.1 & 220 \\
\hline
\end{tabular}


Table 1 continued

\begin{tabular}{|c|c|c|c|c|c|c|c|c|c|c|c|}
\hline & \multirow[t]{2}{*}{ Sex ratio ( $\%$ males) } & \multirow[t]{2}{*}{ MCL (mm) } & \multirow[t]{2}{*}{ Lipids (\%) } & \multicolumn{2}{|c|}{$2 \sum_{17} \mathrm{PCBs}$} & \multicolumn{2}{|c|}{$\mathrm{ICES}_{7} \mathrm{PCBs}$} & \multicolumn{2}{|c|}{$\sum_{11}$ PBDEs } & \multicolumn{2}{|c|}{$\sum_{5} \mathrm{DDTs}$} \\
\hline & & & & Wet & Lipid & Wet & Lipid & Wet & Lipid & Wet & Lipid \\
\hline 2015 & 26 & 314 & 0.49 & 58 & 13,000 & 22 & 5100 & 1.7 & 370 & 1.3 & 300 \\
\hline \multicolumn{12}{|c|}{ Str. Georgia sole } \\
\hline 1997 & 3 & 355 & 0.28 & 2.2 & 820 & 0.9 & 310 & $\mathrm{nfs}$ & $\mathrm{nfs}$ & 1.0 & 450 \\
\hline 1998 & 2 & 351 & 0.25 & 4.2 & 1700 & 1.6 & 640 & $\mathrm{nfs}$ & $\mathrm{nfs}$ & 0.4 & 220 \\
\hline 1999 & 5 & 380 & 0.24 & 2.1 & 900 & 0.8 & 350 & $\mathrm{nfs}$ & $\mathrm{nfs}$ & 0.8 & 440 \\
\hline 2000 & 12 & 350 & 0.81 & 4.9 & 610 & 1.9 & 240 & $\mathrm{nfs}$ & $\mathrm{nfs}$ & 1.1 & 130 \\
\hline 2001 & 5 & 348 & 0.63 & 5.5 & 890 & 2.1 & 340 & $\mathrm{nfs}$ & $\mathrm{nfs}$ & 2.0 & 330 \\
\hline 2003 & 26 & 306 & 0.40 & 6.8 & 1800 & 2.6 & 680 & $\mathrm{nfs}$ & $\mathrm{nfs}$ & 1.6 & 480 \\
\hline 2005 & 15 & 325 & 0.42 & 1.2 & 270 & 0.4 & 110 & 0.83 & 210 & 0.5 & 120 \\
\hline 2007 & 13 & 299 & 0.45 & 1.4 & 330 & 0.5 & 130 & 0.97 & 240 & 0.6 & 140 \\
\hline 2009 & 9 & 321 & 0.31 & 2.7 & 920 & 1.1 & 350 & 0.50 & 170 & 0.5 & 150 \\
\hline 2011 & 13 & 328 & 0.37 & 6.0 & 1900 & 2.3 & 720 & 1.4 & 410 & 0.9 & 270 \\
\hline 2013 & 1 & 375 & 0.49 & 1.2 & 240 & 0.4 & 94 & 0.31 & 63 & 0.5 & 96 \\
\hline 2015 & 2 & 372 & 0.49 & 4.9 & 1000 & 1.9 & 400 & 0.28 & 60 & 0.5 & 98 \\
\hline \multicolumn{12}{|c|}{ Vendovi Is. sole } \\
\hline 1997 & 8 & 255 & 0.22 & 1.0 & 450 & 0.4 & 170 & $\mathrm{nfs}$ & nfs & 0.5 & 300 \\
\hline 1998 & 23 & 275 & 0.29 & 2.5 & 880 & 1.0 & 340 & $\mathrm{nfs}$ & $\mathrm{nfs}$ & 0.3 & 110 \\
\hline 1999 & 3 & 278 & 0.41 & 2.0 & 500 & 0.8 & 190 & $\mathrm{nfs}$ & $\mathrm{nfs}$ & 0.6 & 160 \\
\hline 2000 & 5 & 279 & 0.45 & 2.3 & 520 & 0.9 & 200 & $\mathrm{nfs}$ & $\mathrm{nfs}$ & 0.7 & 180 \\
\hline 2001 & 10 & 275 & 0.45 & 3.2 & 730 & 1.2 & 280 & $\mathrm{nfs}$ & $\mathrm{nfs}$ & 0.9 & 210 \\
\hline 2003 & 10 & 286 & 0.48 & 5.2 & 1100 & 2.0 & 430 & nfs & $\mathrm{nfs}$ & 1.2 & 260 \\
\hline 2005 & 4 & 299 & 0.42 & 0.9 & 210 & 0.3 & 82 & 0.99 & 240 & 0.5 & 110 \\
\hline 2007 & 7 & 285 & 0.28 & 1.6 & 600 & 0.6 & 230 & 0.81 & 290 & 0.6 & 220 \\
\hline 2009 & 13 & 284 & 0.36 & 2.0 & 540 & 0.8 & 210 & 0.33 & 95 & 0.5 & 140 \\
\hline 2011 & 5 & 282 & 0.28 & 5.4 & 1900 & 2.1 & 740 & 1.3 & 450 & 0.6 & 220 \\
\hline 2013 & 6 & 299 & 0.38 & 1.8 & 470 & 0.7 & 180 & 0.61 & 160 & 0.6 & 150 \\
\hline 2015 & 8 & 297 & 0.34 & 4.2 & 1400 & 1.6 & 530 & 0.41 & 160 & 0.3 & 110 \\
\hline
\end{tabular}

ranged from 58, 99, and $160 \mathrm{ng} / \mathrm{g}$ wet wt (Bremerton, Tacoma City Waterway, and Seattle Waterfront) to $270 \mathrm{ng} /$ g wet wt from the Duwamish River (Table 1; Fig. 3). Fish from moderately developed locations had intermediate concentrations (24-29 ng/g wet wt from Everett and Eagle Harbor) and sole from the low-development locations had the lowest concentrations; $20 \mathrm{ng} / \mathrm{g}$ wet wt from Anderson Island, and less than $10 \mathrm{ng} / \mathrm{g}$ wet wt from the remaining three.

As with $2 \sum_{17} \mathrm{PCBs}$, the greatest $\sum_{11} \mathrm{PBDE}$ concentrations in 2015 occurred in three highly developed locations, although concentrations were relatively low overall: 4.3, 4.5, and $6.0 \mathrm{ng} / \mathrm{g}$ wet wt from Duwamish River, Seattle Waterfront, and Tacoma City Waterway (Table 1; Fig. 3). Concentrations of $\sum_{11}$ PBDEs in the seven locations with moderate to low development were less than $2 \mathrm{ng} / \mathrm{g}$ wet wt. Similar to $\sum_{11}$ PBDE, DDTs were low overall, with concentrations ranging from 0.32 to $4.0 \mathrm{ng} / \mathrm{g}$ wet wt across all locations. Greatest $\sum{ }_{5} \mathrm{DDT}$ concentrations occurred at the four highly developed sites, Duwamish River, Seattle Waterfront, Tacoma City Waterway, and Bremerton (4.0-1.3 ng/g wet wt).

Although fish length, percent lipid, and sex ratio covariates (or their interactions) were sometimes significant in the ANCOVA models comparing locations in the current status analysis, they always contributed a minor amount $(<3 \%)$ in explaining the variability in concentration among the ten sites for any of the POPs. Hence, to simplify the site locations analyses, all geometric means reported in Fig. 3 for English sole POPs were computed without covariate adjustments.

\section{English Sole Time Trends}

We did not observe a declining trend in $2 \sum_{17} \mathrm{PCBs}$ from any of the 10 index sites we monitored over the 18-year period from 1997 to 2015 (Fig. 5). Positive, statistically significant $(p<0.05)$ year coefficients indicated increasing 

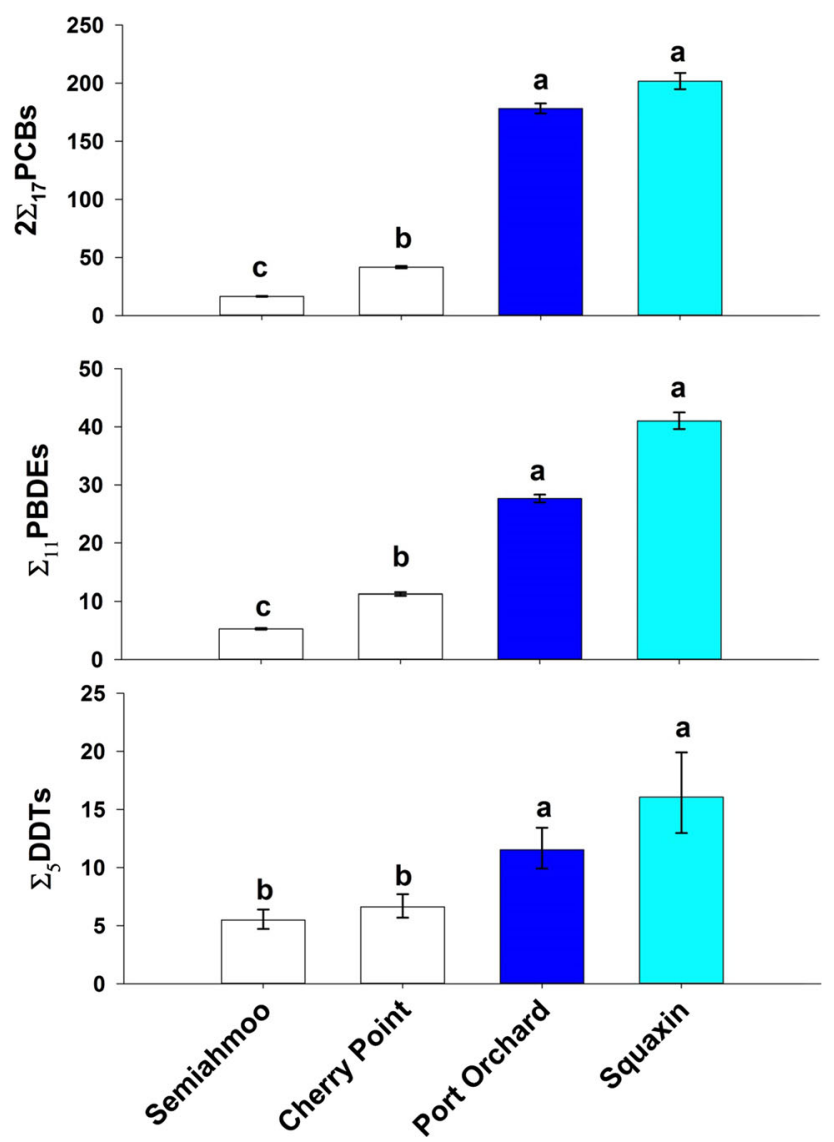

Fig. 2 Geometric mean concentration of $2 \sum_{17} \mathrm{PCB}, \sum_{11} \mathrm{PBDE}$, and $\sum_{5}$ DDTs (ng/g wet wt) in four stocks of Pacific herring from 2014, the most recent sampling period. The levels of basin development are illustrated by color; white for low, cyan for moderate and dark blue for high. For each POP class, sites with the same lower case letter were not significantly different from each other

PCB concentration at two highly developed sites (Tacoma City Waterway and Seattle Waterfront) and two moderately developed sites (Everett and Eagle Harbor), with annual increases from $2.9 \%$ (Eagle Harbor) to $7.1 \%$ (Everett; Table 2). Year was weakly to moderately predictive for these sites (partial $r^{2}$ ranging from 0.16 to 0.41 ; Table 2), and the overall multiple linear regression models for these sites were at best moderately predictive, with final, adjusted $r^{2}$ slightly above 0.50 for only two sites, Tacoma City Waterway, and Everett. English sole from the remaining six index sites exhibited no significant change in PCB concentration over the 19 years. The year coefficient for four of these six sites was not significant $(p>0.05)$, and it was censored as not significant because its partial $r^{2}$ was $<0.10$ at two sites (Anderson Island and Hood Canal). Sex ratio, lipids, or MCL contributed significantly to the final model for eight sites overall and predicted lines were adjusted using grand mean values of the coefficients for significant covariates (Fig. 5). Predicted lines for sites
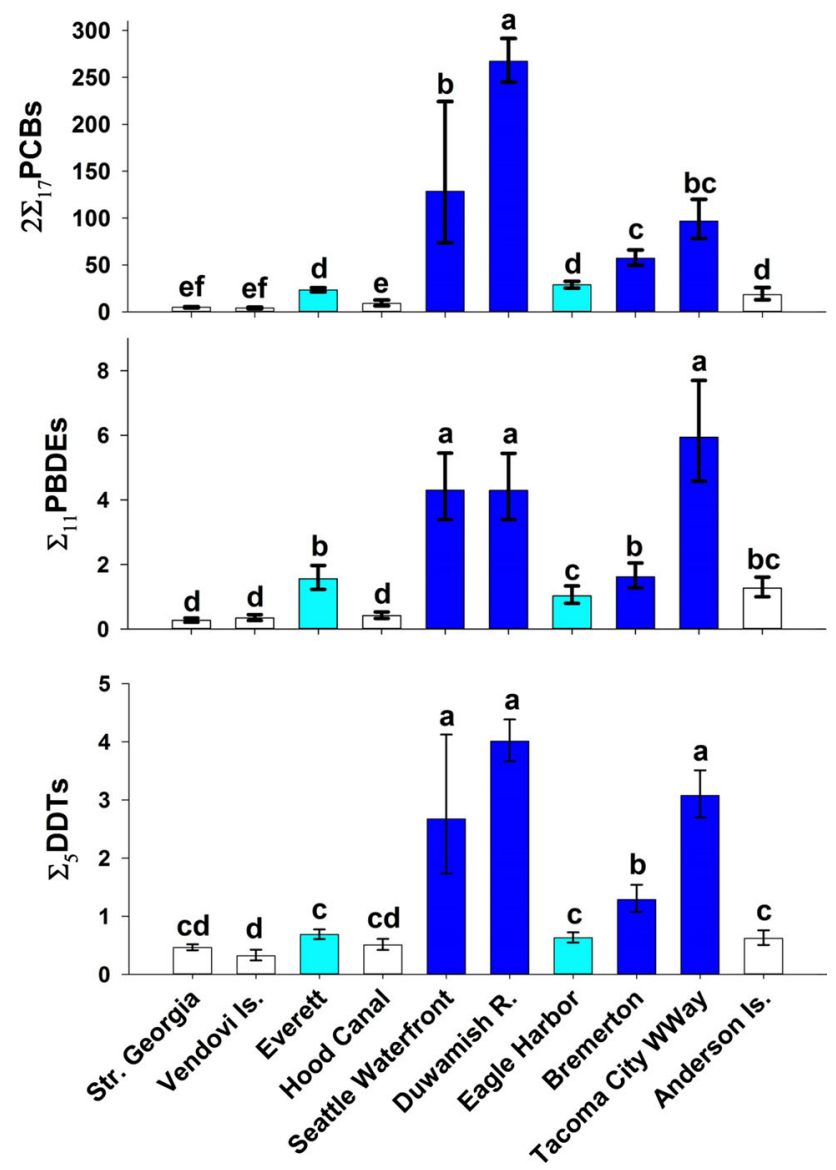

Fig. 3 Geometric mean concentration of $2 \sum_{17} \mathrm{PCB}, \sum_{11} \mathrm{PBDE}$, and $\sum_{5}$ DDTs (ng/g wet wt) in English sole from ten index sites in 2015, the most recent sampling effort. Levels of site development are illustrated by color; white for low, cyan for moderate and dark blue for high. For each POP class, sites with the same lower case letter were not significantly different from each other

where there was no significant trend were calculated and are shown in Fig. 5 as dashed, for reference.

Although year was a weak predictor for $\sum_{11}$ PBDEs overall in English sole ( $r^{2}$ ranged from 0.11 to 0.17 ), the concentrations of $\sum_{11}$ PBDEs with $r^{2}>0.10$ declined significantly at two highly developed sites (Bremerton, $4.0 \%$ and Seattle Waterfront, 3.7\%) and at one low-development site (Vendovi Island, 7.2\%; Fig. 5; Table 2). The year coefficient was not significant for five sites $(p>0.05)$ and it was censored as not significant, because its partial correlation coefficient was $<0.10$ at two sites (Everett and Hood Canal). Fish size, lipids, and sex ratio were weakly to moderately predictive ( $r^{2}$ from 0.06 to 0.56 ) for nine sites, and predicted lines were adjusted using grand mean coefficient values for significant covariates (Fig. 5). Predicted lines for sites where the time trend was not significant were calculated and are shown in Fig. 5 as dashed, for reference. 


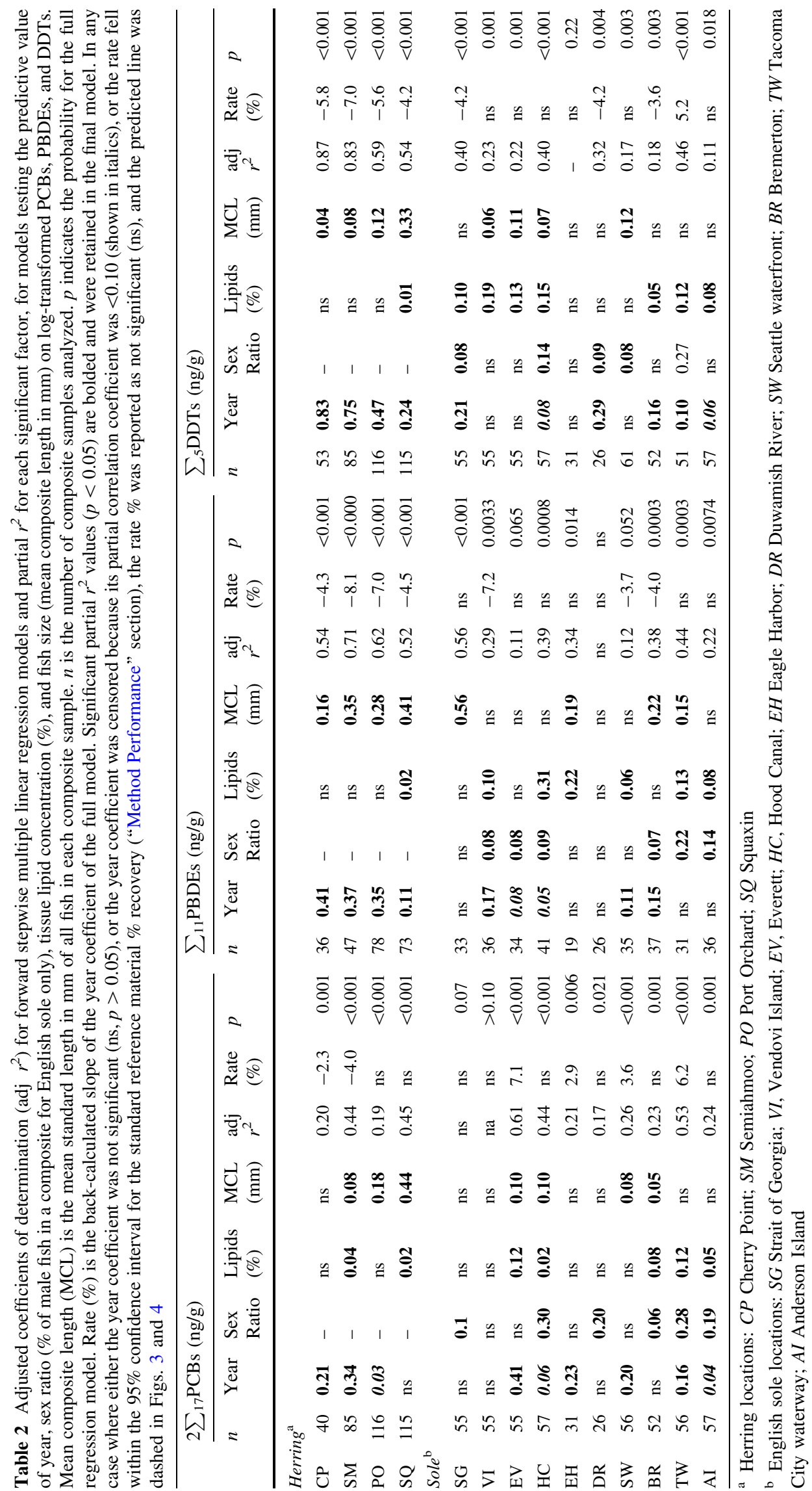


Fig. 4 Temporal trend in $2 \sum_{17} \mathrm{PCBs}, \sum_{11} \mathrm{PBDEs}$, and $\sum_{5}$ DDTs in Pacific herring from four stocks in Puget Sound, WA, sampled from a highly developed basin (Port Orchard stock), moderately developed basin (Squaxin stock) and low-development basin (Semiahmoo and Cherry Point stocks). Dashed lines indicate regression models where year was not significant $(p>0.05)$ or censored as trivial (partial $\left.r^{2}<0.10\right)$ (a) Port Orchard

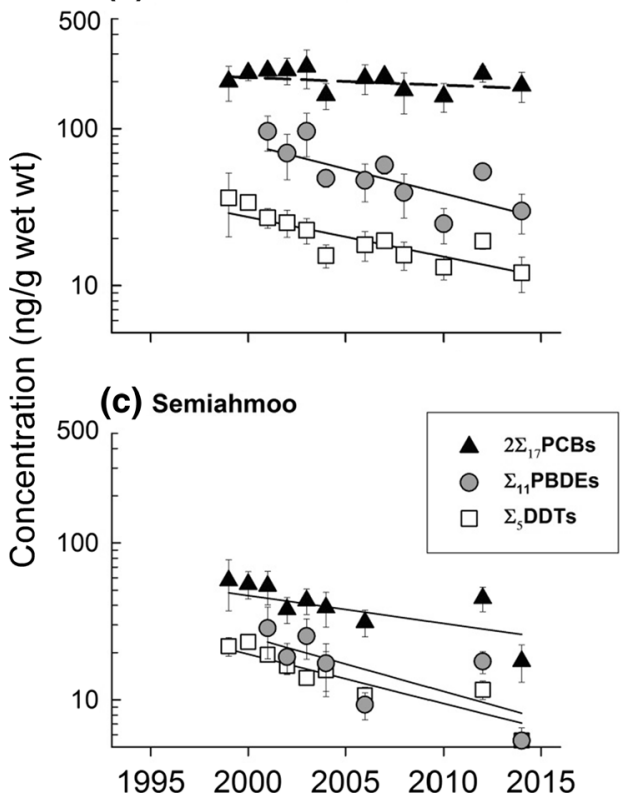

(b) Squaxin

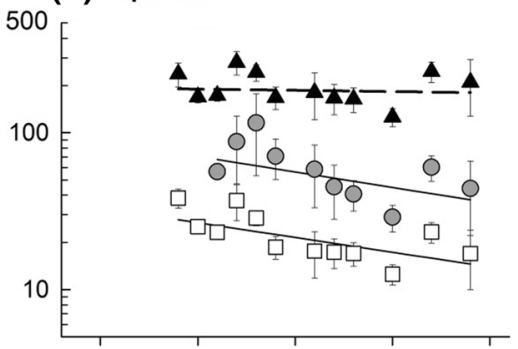

(d) Cherry Point

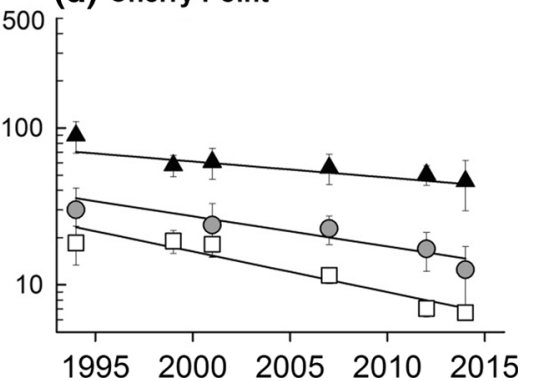

Concentrations of $\sum_{5}$ DDTs declined in English sole from two highly developed sites (Duwamish River, 4.2\% and Bremerton, 3.6\%) and from one low-development site (Strait of Georgia, 4.2\%; Table 2; Fig. 5). One highly developed site (Tacoma City Waterway) exhibited an increase in $\sum_{5}$ DDTs, with an annual rate of $5.2 \%$. Year was not significant $(p>0.05)$ or censored as not significant $\left(r^{2}<0.10\right)$ for the remaining six sites (Table 2). As with $2 \sum_{17} \mathrm{PCBs}$ and $\sum_{11} \mathrm{PBDE}$, full models for $\sum_{5}$ DDTs were weakly to moderately predictive, with $r^{2}$ ranging from 0.11 to 0.46 . Predicted lines shown in Fig. 5 were calculated using grand mean values for significant covariates. Predicted lines for sites where the $\sum_{5}$ DDTs rate was not significant are shown as dashed, for reference.

\section{Discussion}

\section{Consistency in Monitoring Data}

Monitoring programs are challenged by continually shifting and changing analytical methodologies. Two practices can mitigate loss of consistency when methods change: (1) conducting paired analyses by both old and new methods to generate correction factors, and (2) retaining archived tissues for reanalysis once new methods are developed, validated, and then adopted. Each of these practices requires additional cost for duplicate or reanalysis or raises concerns related to sample quality over time. In this study we employed both practices: PBDEs were always conducted using one methodology, with older archived samples analyzed along with current samples to build a time series.
Other long-term monitoring studies have employed this practice, including Ross et al. (2013) who used it to construct the Puget Sound harbor seal time trend line reported earlier herein. Correction factors generated from comparing outdated methods with newer methods appeared to have provided a good tool for correcting biases in our longterm monitoring program. Linear regressions of paired data (old vs. new methods) typically provided excellent fit, with strong coefficients of determination (usually $>0.90$ ), and sufficient homoscedasticity to accept significant correlation coefficients as correction factors.

\section{POPs in Herring}

The long-term trend analyses indicate PCB tissue residues declined in both stocks of Pacific herring from the lowdevelopment basin, however they remained unchanged in the highly and moderately developed basins. This pattern is consistent with PCB trends in harbor seals, a primary predator of herring, sampled from the south Puget Sound, the moderately developed basin. Although harbor seals exhibited a steep decline in blubber PCBs from the 1980s to 1990 s (prior to this study), PCBs remained unchanged or declined only slightly in the most recent years (2003-2009; Ross et al. 2013). A number of studies have demonstrated exponential declines in PCBs in pelagic species in marine and large freshwater ecosystems in the 1980s, with concentrations leveling off over the past decade or two, including herring (Bignert et al. 1998; Miller et al. 2013) and sprat (Szlinder-Richert et al. 2009) from the Baltic Sea, and marine fishes, birds, and mammals from the Canadian Arctic (Braune et al. 2005). Coho and Chinook salmon in 
Fig. 5 Temporal trend in $2 \sum_{17} \mathrm{PCBs}, \sum_{11} \mathrm{PBDEs}$, and $\sum_{5}$ DDTs in English sole from ten index sites in Puget Sound. Dashed lines indicate regression models where year was not significant $(p>0.05)$ or censored as trivial (partial $\left.r^{2}<0.10\right)$ (a) Seattle Waterfront

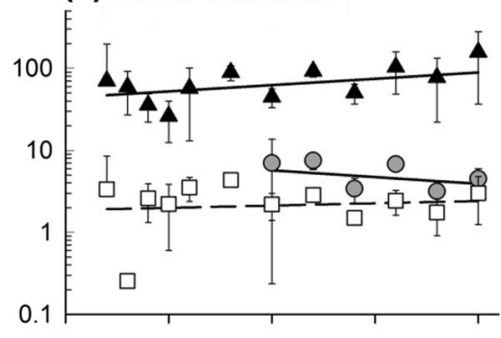

(c) Tacoma City Waterway

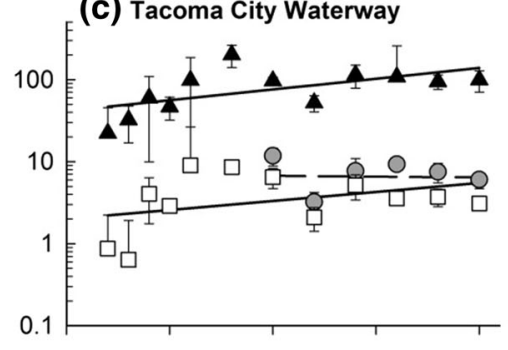

(e) Eagle Harbor

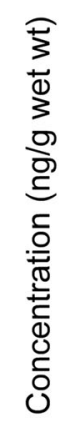

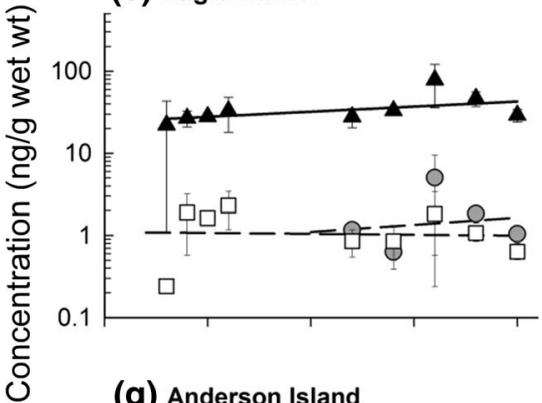

(g) Anderson Island
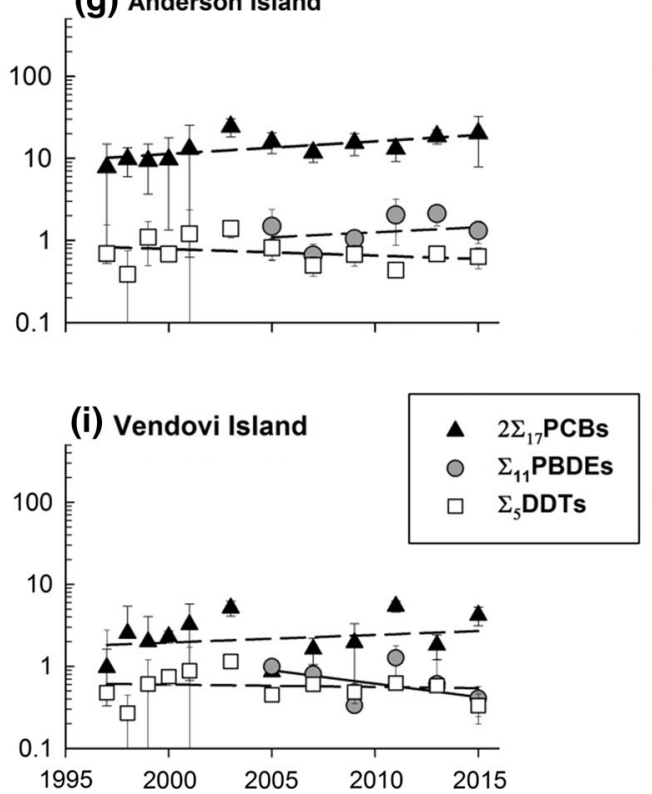

(b) Duwamish River

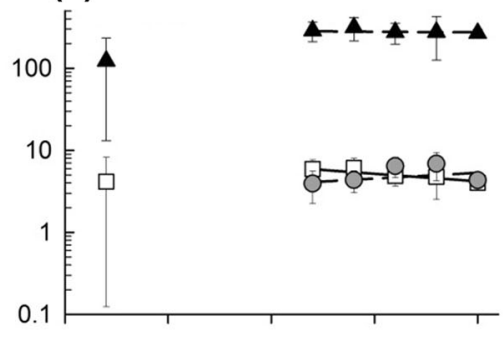

(d) Bremerton
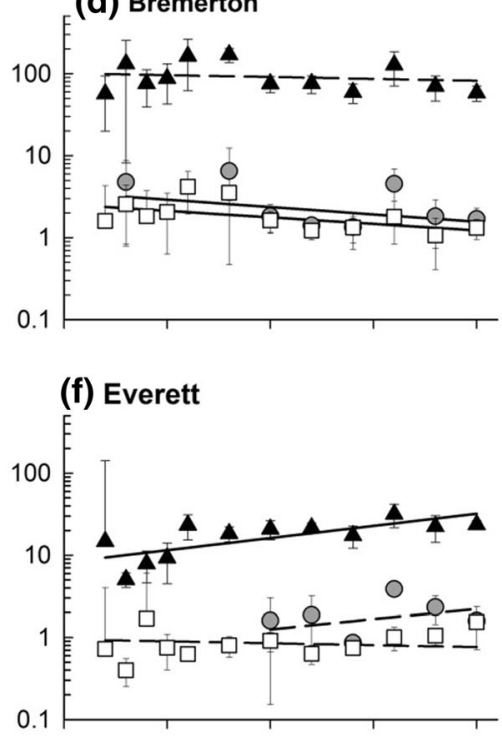

(h) Hood Canal

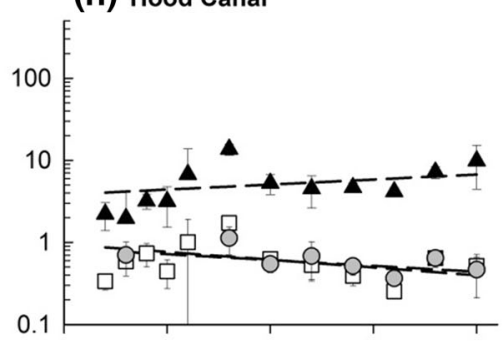

the US Great Lakes followed a rapid first order kinetics PCB decline in the 1980s but subsequently leveled off to a non-zero steady state (Stow et al. 1994; Lamon et al. 1999).

PCB concentrations in central and southern Puget Sound herring were considerably higher than levels reported in herring from the most highly developed areas of the southern Baltic Sea sampled during the same time period. Szlinder-Richert et al. (2009) reported mean $\mathrm{ICES}_{7}$ PCBs in muscle tissue of Baltic herring ranging from 15 to $27 \mathrm{ng} /$ g wet wt and 360-820 ng/g lipid wt from 1997 to 2006. 
Because we sampled whole male fish of a relatively fixed size and reported an estimate of total PCBs (2 $\left.\sum_{17} \mathrm{PCBs}\right)$, a direct comparison of PCB wet wt results was inappropriate. Instead, we limited our comparison to concentrations of $\mathrm{ICES}_{7}$ PCBs on lipid weight to mitigate the difference in tissue types and PCB summation methods. Whole Pacific herring from central and southern Puget Sound were roughly two times higher than those reported in southern Baltic herring muscle samples, with $\mathrm{ICES}_{7} \mathrm{PCBs}$ calculated in the Puget Sound herring ranging from 690 to $1800 \mathrm{ng} / \mathrm{g}$ lipid weight from a similar time period (1999-2006; Table 1). Southern Baltic herring PCB levels were more similar to concentrations we observed in the two stocks from the Strait of Georgia (least-developed basin), with concentrations ranging from 250 to $900 \mathrm{ng} / \mathrm{g}$ lipid. These comparisons were somewhat confounded by differences in fish size and sex; southern Baltic herring from Szlinder-Richert et al. (2009) were larger, with maximum sizes reported as $305 \mathrm{~mm}$ compared with mean composite lengths of Pacific herring ranging from 143 to $181 \mathrm{~mm}$. Based on size, Pacific herring in the current study were likely younger than those used in the Baltic study, and so may have experienced a shorter duration of exposure to PCBs. Moreover, the selection of only male herring in the Puget Sound study likely would have increased PCB differences if female fish (represented in the Baltic samples) were depurating POPs during reproduction.

PCB concentrations in Puget Sound herring were within the range reported for two forage fish species, silversides (Menidia audens) and topsmelt (Atherinops affinis), in San Francisco Bay from 2010 (Greenfield and Allen 2013). These authors reported mean concentrations for sum of 209 PCBs (equivalent to our $2 \sum_{17} \mathrm{PCBs}$ ) of $138 \mathrm{ng} / \mathrm{g}$ wet wt from "ambient," randomly selected sites, and $441 \mathrm{ng} / \mathrm{g}$ wet wt from sites known to be highly PCB-contaminated. These species were selected by Greenfield and Allen (2013) for similar reasons herring were selected in the present study; herring, topsmelt, and silversides represent small, schooling, midwater prey upon which many higher predators rely and therefore can illustrate an important pathway for POPs like PCBs. Some significant differences between the species prevent an unqualified comparison: the San Francisco silversides and topsmelt were much smaller, roughly half the size of Puget Sound herring, and they exhibited somewhat lower lipids than two of the Puget Sound stocks. Additionally, they likely exhibit somewhat different feeding ecology; topsmelt and silversides were thought to represent local sediment conditions, by feeding on organisms near to the seafloor in shallow waters, whereas herring in Puget Sound likely forage more widely, in much deeper waters, on more pelagic prey.

These Puget Sound and other studies underscore the environmentally recalcitrant characteristics of PCBs, the importance of pelagic biota as a sink for these chemicals, and the role pelagic fishes play as vectors of PCBs to apex predators. Rice et al. (2012) reported Pacific herring as the second most frequently encountered forage fish in a study of Puget Sound surface waters, after juvenile Chinook salmon. These species were encountered in well over $50 \%$ of all surface trawls conducted in the same basins represented in the current study. Pacific herring are thought to exert bottom-up ecosystem control in Puget Sound, based on Ecopath/Ecosim modeling (Harvey et al. 2012), and indeed they are one of several midwater fishes that dominate the diet of harbor seals, Puget Sound's most abundant resident fish-eating marine mammal. Pacific herring, tomcod, hake and salmon were estimated to constitute over $60 \%$ of harbor seal diet (Cullon et al. 2005).

O'Neill and West (2009) posited residence time in Puget Sound (i.e., feeding on Puget Sound-resident prey) as a risk factor for PCB accumulation in migratory species that move through this system. Elevated levels of PCBs have been documented in species throughout Puget Sound's pelagic food web, from plankton (West et al. 2011a) to Puget Sound-resident pelagic fish predators (West et al. 2011b), migratory adult salmon (Cullon et al. 2009; O'Neill and West 2009), marine birds (Good et al. 2014), and marine mammals including resident harbor seals (Ross et al. 2004) and migratory fish-eating killer whales (Ross et al. 2000, Krahn et al. 2007, 2009).

The monitoring program forming the basis of this paper compares POP tissue residues in fish to published critical body residues (CBR; Meador et al. 2011) to predict health impairment. Using this CBR concept, PCB and PBDE concentrations in some herring stocks are cause for concern. Current (2014) PCB concentrations in herring from Port Orchard (3400 ng/g lipid) and Squaxin (4800 ng/g lipid) stocks in this study (Table 1) exceeded a $2400 \mathrm{ng} / \mathrm{g}$ health effects threshold determined for juvenile salmon (Meador et al. 2002; the most appropriate CBR for herring from current literature). Because herring sampled in this study were male fish targeted at age 3 years, it is likely that older male fish could have substantially higher POP concentrations (and, conversely, lower levels in younger fish and females of spawning age). Juvenile salmon exposed to PCBs in the range of exposures we observed in Squaxin and Port Orchard herring exhibited a number of health effects including increased enzyme activity, altered thyroid hormones, and increased mortality. Trophic transfer of PCBs via herring also presents a health risk to their predators; $22 \%$ of adult Chinook salmon sampled from Puget Sound exceeded the Meador et al. (2002) CBR for PCBs (O'Neill and West 2009). Furthermore, adult Chinook salmon (Cullon et al. 2009; Mongillo et al. 2016) and other pelagic fishes (Cullon et al. 2005; West et al. 2011b) from the Salish Sea (including Puget Sound) were 
identified as key vectors of PCBs to killer whales and harbor seals, both important apex predators in the ecosystem. Using this exposure pathway, Hickie et al. (2007) predicted PCBs in Southern Resident killer whales feeding in Puget Sound would not fall below a 17-mg total PCBs/ $\mathrm{kg}$ blubber lipids health-effects threshold concentration until the year 2063. Additionally, the Washington Department of Health (WDOH) has recommended restricting human consumption of Chinook salmon residing in Puget Sound because of PCB contamination in that species (Washington Department of Health 2015).

Although PCBs are still of significant concern in Puget Sound's pelagic food web almost 40 years after their production and legal use was banned, decreasing trends of PBDEs and DDTs in all herring stocks point to the success of remediation and control efforts for POPs in Puget Sound. Washington State recommended reductions in PBDE use as early as 2006 (Washington Department of Ecology 2006), and its state legislature restricted further use of PBDEs in 2008. These actions were taken to reduce exposure of humans to PBDEs and to mitigate input of PBDEs to Puget Sound. PBDE reductions notwithstanding, current (2014) tissue levels may still be high enough to impair herring health. Methodological differences in measuring and reporting PBDE concentrations hinder direct interpretation of published PBDE CBRs with the concentrations we reported in Table 2. However, Tomy et al. (2004) and Arkoosh et al. (2017) reported variations in thyroid homeostasis related to dietary doses of PBDEs that produced tissue burdens similar to those we observed in wild herring. In particular, Arkoosh et al. (2017) observed depressed tri-iodothyronine (T3) in plasma of juvenile Chinook salmon with a PBDE body burden of $37 \mathrm{ng} / \mathrm{g}$ wet wt (for a mixture of two dominant congeners typically observed in fish samples, PBDE 47 and 99). We reported a similar range of $\sum_{11} \mathrm{PBDE}$ concentrations; 30 and $44 \mathrm{ng} / \mathrm{g}$ wet wt from Squaxin and Port Orchard herring stocks in 2014, and PBDE 47 and 99 were also the most abundant congeners in our samples, accounting for approximately $67 \%$ of the $\sum_{11}$ PBDE concentration. Tomy et al. (2004) reported depressed thyroxine levels in plasma of lake trout fed "low" and "high" doses of a mixture of 13 PBDEs resulting in maximum lipid-adjusted tissue concentrations of 150 to $1600 \mathrm{ng}$ PBDEs/g lipids (manual summation of concentrations in their Fig. 1) compared with $410-1000 \mathrm{ng} / \mathrm{g}$ lipids for the four herring stocks that we reported from Puget Sound. Arkoosh et al. (2010; Fig. 2a) reported increased disease susceptibility in juvenile Chinook salmon dosed with five commonly observed PBDE congeners (47, 99, 100, 153, and 154) resulting in total PBDE concentrations similar to what we observed in our field sampled herring.
Assuming that herring respond similarly to Chinook salmon, we would predict some impairment of herring health related to PBDE exposure.

Unlike PCBs and PBDEs, DDT concentrations in all herring were well below a CBR for whole fish of $600 \mathrm{ng} / \mathrm{g}$ wet wt (Beckvar et al. 2005); the greatest concentration of $\sum_{5}$ DDTs observed in the current study was $39 \mathrm{ng} / \mathrm{g}$ wet $\mathrm{wt}$, suggesting DDTs alone posed less risk to herring than the other POPs we measured. However, a tissue residue approach designed to evaluate the toxicity of chemical mixtures (Dyer et al. 2011) for the 3 POP categories we measured may be appropriate for future analyses.

\section{POPs in English Sole}

Whereas Pacific herring (this report) and other pelagic species (West et al. 2011a, b) exhibited pervasive POP contamination of the pelagic food web in highly or moderately developed oceanographic basins (on the order of hundreds of square $\mathrm{km}$ ) in Puget Sound, English sole illustrated POP conditions at a smaller spatial scale (probably a few square $\mathrm{km}$ ), related to their proximity to contaminated sediments and limited home range (O'Neill et al. 2007). Results reported for English sole herein are congruent with sediment conditions reported by a companion Puget Sound sediment monitoring program, which measured contaminants in sediments collected near our English sole sampling sites. Long et al. (2005) characterized only approximately $1 \%$ of Puget Sound sediments as being significantly impaired by toxic chemicals, including PCBs and DDTs, all of which occurred in close proximity to the same four urban centers where we observed the most contaminated English sole (the bays and shorelines near Seattle, Tacoma, Bremerton, and Everett). English sole exhibited feeding-site fidelity and a small foraging area in an acoustic tagging study (O'Neill et al. 2007), further validating the use of this species as an indicator of more local, bay-scale conditions.

Relatively high PCB concentrations and their increase (or lack of decline) in English sole indicates efforts to control these chemicals in Puget Sound waters have not been effective enough to achieve declining trends. Moreover, mean ICES $_{7}$ PCB levels in English sole from four urban sites (55 ng/g from Seattle Waterfront, Tacoma City Waterway, Duwamish River and Bremerton sites combined) were approximately 12 times higher than the $4.6 \mathrm{ng} /$ $\mathrm{g}$ wet wt reported in confamilial European flounder (Platichthys flesus) from densely populated and highly urbanized areas in the Baltic Sea in the most recent year when both programs measured these species [Table 1 herein, and Table 2 in Szlinder-Richert et al. (2009)]. Unlike Pacific herring, comparison between Puget Sound and Baltic flatfishes was not confounded by tissue type (skin-off fillets 
were analyzed for both), so comparison of the original wet wt was appropriate, and only required a correction from the $2 \sum_{17} \mathrm{PCB}$ to $\mathrm{ICES}_{7} \mathrm{PCB}$ for the English sole. Based on ICES7 PCBs, the PCB levels in European flounder from urbanized areas of the Baltic Sea Szlinder-Richert et al. 2009) were more similar to PCBs in English sole from the least developed Puget Sound sites ( $3.8 \mathrm{ng} / \mathrm{g}$ wet wt; mean from Strait of Georgia, Vendovi Island, Hood Canal, and Anderson Island).

These observations are consistent with Brown et al. (1998), who documented increasing PCBs in English sole from 1984 to 1990 at two highly developed sites near the Seattle Waterfront and the Tacoma City Waterway sampled in the current study. They also reported no change in PCBs near our low-development Anderson Island site, where we also reported no declining PCB trend. Brown et al. (1998) concluded that redistribution of sediment particles from depositional areas in deeper parts of the contaminated urban bays or continued inputs from existing onshore sources likely accounted for the increase trends they observed in PCB concentration at these highly developed sites. Although it is difficult to track all in-water activities in the urban waterways where English sole were collected for this study, many of them experienced significant anthropogenic sediment-disturbing activities throughout our 19-year monitoring period, including sediment removal via dredging for navigation or for contaminant remediation. Other factors that may have prevented PCB declines in English sole include: (1) recirculation of persistent congeners in the benthic food web; (2) new PCB inputs that have not been adequately controlled; and (3) increasing wastewater and stormwater conveyance of PCBs related to increases in human population in the region that may offset source control efforts.

The $\sum_{11} \mathrm{PBDEs}$ and $\sum_{5} \mathrm{DDT}$ declined or remained unchanged in all English sole with one exception, the 5.2\% annual increase of $\sum_{5}$ DDTs in English sole from the Tacoma City Waterway. The levels of $\sum_{11}$ PBDEs and $\sum_{5}$ DDTs at many English sole sites were heading in a desirable direction (declining) and all concentrations were low (especially compared with $2 \sum_{17} \mathrm{PCBs}$ ), with values that varied narrowly, near the limit of quantitation for many of the analytes used in the summations. In these cases, trends should be interpreted with caution because of the possibility of true trends being obscured by method performance near the limits of quantitation. In addition, recovery of DDT analytes in standard reference materials was particularly problematic because of interference with unknown chemicals, and inconsistent performance through time that was difficult to quantify. These cautions notwithstanding, $\sum_{5}$ DDTs in English sole from the Tacoma City Waterway is particularly notable, because it showed a relatively strong increasing trend. The Tacoma
City Waterway index site is located near the mouth of the Puyallup River, which receives runoff from agricultural, residential, and urbanized lands. Johnson et al. (1988) noted recalcitrant DDTs from agricultural soils can be a significant source of DDTs in Washington rivers as a result of erosion, which may explain the source of DDTs at the Tacoma site. This site also has experienced a number of dredging and cleanup operations, as well as removal of contaminated shoreline soils, which may have exposed otherwise sequestered DDTs.

Similar to San Francisco Bay marine fish (Davis et al. 2007), a primary concern regarding PCBs in English sole is protection of human health from contaminated seafood. PCB concentrations in English sole were high enough to generate advice restricting consumption from five of the ten Puget Sound index sites in the current report; Tacoma City Waterway, Duwamish River, Eagle Harbor, Seattle Waterfront, and Bremerton (Washington Department of Health 2015). Furthermore, PCBs in English sole from these five sites, plus those from Anderson Island and Everett exceeded a human health screening value $(10 \mathrm{ng} / \mathrm{g}$ wet wt) for marine fish in San Francisco Bay (Davis et al. 2007). PBDEs (0.28-6.0 ng/g wet wt) and DDTs $(0.30-3.1 \mathrm{ng} / \mathrm{g}$ wet $\mathrm{wt})$ in English sole were low relative to fish-health CBRs; that is, near to PBDE concentrations reported for experimental controls in Arkoosh et al. (2010) and more than 100 times lower than the Beckvar et al. (2005) DDT threshold of $600 \mathrm{ng} / \mathrm{g}$ wet wt.

\section{Challenges to Reducing POPs}

Evaluation of best management practices to mitigate POPs in the marine environment requires a full understanding of not only the sources of POPs to the system but also the fate and transport of POPs in the system (Arnot and Gobas 2004; Osterberg and Pelletier 2015). The POPs selected for tracking in this long-term monitoring program cover a wide range of hydrophobicity and half-lives, with most considered environmentally recalcitrant (Johnson et al. 2014). For example, Fisk et al. (1998) reported biomagnification factors $(\mathrm{BMF})$ for the $16 \mathrm{PCB}$ congeners we quantitated ranging from 1 to 16 , and half-lives of 44-224 days, with slow or no metabolism of this group in fish (for a low dose scenario). Similarly, Tomy et al. (2004) reported BMFs for PBDEs in lake trout ranging from 2.1 to 18 , and half-lives of 38-210 days, although accurate assessment of PBDE BMFs is hampered by biotransformation of highly brominated (e.g., deca-molecules) to lower brominated forms within fish. Although POPs can degrade in the environment by photolysis (e.g., PBDEs; Fang et al. 2008) the more likely degradation mechanisms for POPs in biota are biological, because light may not penetrate solid matrices, such as sediments and tissues (Johnson et al. 2014). 
Metabolic breakdown of PCBs in marine sediments can occur by bacteria (Papale et al. 2016; Matturro et al. 2016); however, the extent of this degradation capacity is unknown.

POPs in our benthic indicator (English sole) clearly reflected sediment conditions where they foraged; however, POPs may enter pelagic food webs via more complex mechanisms. Others have shown POP uptake into pelagic food webs directly from surface waters via ad/absorption by bacteria, other microplankton, and phytoplankton (Larsson et al. 2000; Hudson et al. 2005). Sinking POPladen particles that may otherwise reach the seafloor in shallow systems can be intercepted by vertically migrating zooplankton, such as krill (Euphausia spp; Dilling et al. 1998) in deeper systems. These species are known to concentrate and feed on sinking particulates at the density gradient, where the sinking rate of particles is slowed (Dilling and Alldredge 2000) and which is a characteristic of deeper, vertically stratified systems, such as Puget Sound. The disparity in POP status and trends we observed between herring and English sole probably reflects these processes, and a deeper investigation of these processes may better inform the development of best management practices to mitigate POPs in systems like Puget Sound. Reduction of POPs in English sole may achieved most directly by reducing POPs in sediments from highly developed embayments. POP reductions in the pelagic food web may be more complicated and more responsive to reducing POPs in the water column, whether originating from stormwater or nonpoint sources, point-source inputs, sediment resuspension, atmospheric transport, or trophic recirculation within the pelagic food web.

\section{Conclusions}

Relatively high and static levels of PCBs in Pacific herring from the moderately and highly developed Puget Sound basins (this study), as well as from resident pelagic fishes in other large coastal estuaries, such as San Francisco Bay (Davis et al. 2007) and the Baltic Sea (Szlinder-Richert et al. 2009) underscore the persistence of PCBs in the pelagic food webs of nearshore, relatively enclosed marine ecosystems. Remediation efforts to date seem to have reduced PCBs from high levels in the 1970s and 1980s; however, levels of significant concern continue. PCBs in Puget Sound's benthic indicator species appear to be increasing in several urbanized areas, and not decreasing in any sampled location. Particular challenges identified by these studies may be to develop methods for reducing new PCB sources to the pelagic food web and to understand the causes for PCB increases in benthic species from urbanized locations. Puget Sound's pelagic prey base continues to be a hot-spot of PCBs in the northeastern Pacific Ocean region, resulting in longterm contamination of apex predators and other species important to healthy ecosystem function and to human use. Recovery of at least two species listed for protection and recovery by the U.S. Endangered Species Act and Canadian Species at Risk Act, southern resident killer whales (Krahn et al. 2002) and Chinook salmon (Myers et al. 1998) may be significantly hindered by their exposure to PCBs from their prey base in Puget Sound (Hickie et al. 2007; O'Neill and West 2009; Mongillo et al. 2016). PBDEs and DDTs appear to be on the decline in both benthic and pelagic species, except for a few notable exceptions, suggesting that efforts to reduce or remove these chemicals have been largely successful. Continued tracking of POPs in benthic species, such as English sole, will continue to provide a measure of efficacy of more local cleanup or remediation efforts.

Acknowledgments This project was funded by the State of Washington and the US Environmental Protection Agency in support of the Puget Sound Ecosystem Monitoring Program's efforts to track the health of the Puget Sound ecosystem. The authors gratefully acknowledge the dedicated efforts of scores of technicians and scientists from the Washington Department of Fish and Wildlife who have participated in this program over its long history, including Gregory Lippert, Stephen Quinnell, Kit Hoeman, Kurt Stick, Pat McAllister, Jennifer Lanksbury, Laurie Niewolny, and Andrea Carey. Mariko Langness contributed to the graphics in this paper. Kurt Dobszinsky and his crew of the F/V Chasina provided excellent support in the field, and collected all the fish used in this study. In addition, this program benefitted greatly from careful and consistent laboratory analyses and support by scientists at the US National Oceanic and Atmospheric Administration's Northwest Fisheries Science Center, including Donald Brown, Margaret Krahn, Tracy Collier, Daryle Boyd, Bernadita Anulacion, Richard Boyer, Jonelle Herman, Catherine Sloan, Ronald Pearce, Karen Tilbury and Jennie Bolton. This manuscript was greatly improved by contributions from two anonymous reviewers.

Open Access This article is distributed under the terms of the Creative Commons Attribution 4.0 International License (http://crea tivecommons.org/licenses/by/4.0/), which permits unrestricted use, distribution, and reproduction in any medium, provided you give appropriate credit to the original author(s) and the source, provide a link to the Creative Commons license, and indicate if changes were made.

\section{References}

Arkoosh MR, Boylen D, Dietrich J, Anulacion BF, Ylitalo G, Bravo CF, Johnson LL, Loge FJ, Collier TK (2010) Disease susceptibility of salmon exposed to polybrominated diphenyl ethers (PBDEs). Aquatic Toxicol 98:51-59

Arkoosh MR, Van Gaest AL, Strickland SA, Hutchinson GP, Krupkin AB, Dietrich JP (2017) Alteration of thyroid hormone concentrations in juvenile chinook salmon (Oncorhynchus tshawytscha) exposed to polybrominated diphenyl ethers, BDE-47 and BDE99. Chemosphere 171:1-8

Arnot JA, Gobas FAPC (2004) A food web bioaccumulation model for organic chemicals in aquatic ecosystems. Environ Toxicol Chem 23(10):2343-2355 
Beckvar N, Dillon TM, Read LB (2005) Approaches for linking whole-body fish tissue residues of mercury or DDT to biological effects thresholds. Environ Toxicol Chem 24(8):2094-2105

Bignert A, Olsson M, Persson W, Jensen S, Zakrisson S, Litzen K, Eriksson U, Haggberg L, Alsberg T (1998) Temporal trends of organochlorines in Northern Europe, 1967-1995. Relation to global fractionation, leakage from sediments and international measures. Environ Poll 99(2):177-198

Braune BM, Outridge PM, Fisk AT, Muir DCG, Helm PA, Hobbs K, Hoekstra PF, Kuzyk ZA, Kwan M, Letcher RJ, Lockhart WL, Norstrom RJ, Stern GA, Stirling I (2005) Persistent organic pollutants and mercury in marine biota of the Canadian Arctic: an overview of spatial and temporal trends. Sci Total Environ 351-352:4-56

Brown DW, McCain BB, Horness BH, Sloan CA, Tilbury KL, Pierce SM, Burrows DG, Chan S-L, Landahl JT, Krahn MM (1998) Status, correlations, and temporal trends of chemcial contaminants in fish and sediment from selcted sites on the Pacific Coast of the USA. Mar Pollut Bull 37:67-85

Burns R (1985) The shape and form of Puget Sound. University of Washington, Washington Sea Grant Publication, University of Washington Press, Seattle, p 100

Cullon DL, Jeffries SJ, Ross PS (2005) Persistent organic pollutants in the diet of harbor seals (Phoca vitulina) inhabiting Puget Sound, Washington (USA), and the Strait of Georgia, British Columbia (Canada): a food basket approach. Environ Toxicol Chem 24(10):2562-2572

Cullon DL, Yunker MB, Alleyne C, Dangerfield NJ, O'Neill S, Whiticar MJ, Ross PS (2009) Persistent organic pollutants in Chinook salmon (Oncorhynchus tshawytscha): implications for resident killer whales of British Columbia and adjacent waters. Environ Toxicol Chem 28(1):148-161

Davis JA, Hetzel F, Oram JJ, McKee LJ (2007) Polychlorinated biphenyls (PCBs) in San Francisco Bay. Environ Res 105(1):67-86

Day DE (1976) Homing behavior and population stratification in central Puget Sound English sole (Parophrys vetulus). J Fish Res Bd Canada 33:278-282

Dilling L, Alldredge AL (2000) Fragmentation of marine snow by swimming macrozooplankton: a new process impacting carbon cycling in the sea. Deep Sea Res Part I 47:1227-1245

Dilling L, Wilson J, Steinberg D, Alldredge A (1998) Feeding by the euphausiid Euphausia pacifica and the copepod Calanus pacificus on marine snow. Mar Ecol Progress Ser 170:189-201

Dodder NG, Maruya KA, Ferguson PL, Grace R, Klosterhaus S, La GuardiaMJ, Lauenstein GG, Ramirez J (2013) Occurrence of contaminants of emerging concern in mussels (Mytilus spp.) along the California coast and the influence of land use, storm water discharge, and treated wastewater effluent. Mar Pollut Bull 81(2):340-346

Dyer S, Warne SJ, Meyer JS, Leslie HA HA, Escher Bl (2011) Tissue residue approach for chemical mixtures. Integr Environ Assess Manag 7:99-115

Fang L, Huang J, Yu G, Wang L (2008) Photochemical degradation of six polybrominated diphenyl ether congeners under ultraviolet irradiation in hexane. Chemosphere 71:258-267

Fisk AT, Norstrom RJ, Cymbalisty CD, Muir DCG (1998) Dietary accumulation and depuration of hydrophobic organochlorines: bioaccumulation parameters and their relationship with the octanol/water partition coefficient. Environ Toxicol Chem 17:951-961

Fry J, Xian G, Jin S, Dewitz J, Homer C, Yang L, Barnes C, Herold N, Wickham J (2011) Completion of the 2006 national land cover database for the conterminous United States. Photogramm Eng Remote Sens 77:858-864
Good TP, Pearson SF, Hodum P, Boyd D, Anulacion BF, Ylitalo GM (2014) Persistent organic pollutants in forage fish prey of rhinoceros auklets breeding in Puget Sound and the northern California Current. Mar Pollut Bull 86(1-2):367-378

Greenfield BK, Allen RM (2013) Polychlorinated biphenyl spatial patterns in San Francisco Bay forage fish. Chemosphere 90(5): 1693-1703

Harrison PJ, Mackas DL, Frost BW, MacDonald RW, Crecelius EA (1994) An assessment of nutrients, plankton, and some pollutants in the water column of Juan de Fuca Strait, Strait of Georgia and Puget Sound, and their transboundary transport. Review of the marine environment and biota of Strait of Georgia, Puget Sound, and Juan de Fuca Strait: proceedings of the BC/Washington symposium on the marine environment, Jan 13 \& 14, 1994. Can Tech Rep Fish Aquat Sci Report No. 1948

Harvey CJ, Williams GD, Levin PS (2012) Food web structure and trophic control in central Puget Sound. Estuaries Coasts 35(3):821-838

Hickie BE, Ross PS, MacDonald RW, Ford JKB (2007) Killer whales (Orcinus orca) face protracted health risks associated with lifetime exposure to PCBs. Environ Sci Technol 41(18):6613-6619

Hudson MJ, Swackhamer DL, Cotner JB (2005) Effect of microbes on contaminant transfer in the lake superior food web. Environ Sci Technol 39:9500-9508

International Council for the Exploration of the Sea (1987) Report of the ICES advisory committee on marine pollution, 1986, International Council for the Exploration of the Sea. Issue 142 of Cooperative Research Report

Jensen S, Johnels AG, Olsson M, Otterlind G (1969) DDT and PCB in marine animals from Swedish waters. Nature 224(5216):247-250

Johnson A, Norton D, Yake B (1988) Persistence of DDT in the Yakima River drainage, Washington. Arch Environ Contam Toxicol 17:289-297

Johnson LL, Anulacion BF, Arkoosh MR, Burrows DG, DaSilva DAM, Dietrich JP, Myers MS, Spromberg J, Ylitalo GM (2014) Effects of legacy peristent organic pollutants (POPs) in fishcurrent and future challenges. In: Tierney KB, Farrell AP, Brauner CJ (eds) Organic chemical toxicology of fishes: Fish Physiology, vol 33. Elsevier Academic Press, Amsterdam

Jones KC, de Voogt P (1999) Persistent organic pollutants (POPs): state of the science. Environ Poll 100(1-3):209-221

Krahn MM, Ylitalo GM, Buzitis J, Sloan CA, Boyd DT, Chan S-L, Varanasi U (1994) Screening for planar chlorobiphenyl congeners in tissues of marine biota by high performance liquid chromatography with photodiode array detection. Chemosphere 29(1):117-139

Krahn MM, Wade PR, Kalinowski S, Dalheim ME, Taylor BL et al (2002) Status review of Southern resident killer whales (Orcinus orca) under the endangered species act. NOAA Technical Memorandum NMFS-NWFSC-54

Krahn MM, Hanson MB, Baird RW, Boyer RH, Burrows DG, Emmons CK, Ford JK, Jones LL, Noren DP, Ross PS, Schorr GS (2007) Persistent organic pollutants and stable isotopes in biopsy samples (2004/2006) from Southern Resident killer whales. Mar Pollut Bull 54(12):1903-1911

Krahn MM, Hanson MB, Schorr GS, Emmons CK, Burrows DG, Bolton JL, Baird RW, Ylitalo GM (2009) Effects of age, sex and reproductive status on persistent organic pollutant concentrations in "Southern Resident" killer whales. Mar Pollut Bull 58(10):1522-1529

Lamon ECI, Carpenter SR, Stow CA (1999) Rates of decrease of polychlorinated biphenyl concentrations in five species of Lake Michigan salmonids. Can J Fish Aquat Sci 56:53-59 
Lanksbury J, Carey A, Niewolny L, West J (2013) Mussel watch pilot expansion 2012/2013: a study of toxic contaminants in blue mussels (Mytilus trossulus) from Puget Sound, Washington, USA. Washington Dpartment of Fish and Wildlife, Olympia

Larsson P, Andersson A, Broman D, Nordbäck J, Lundberg E (2000) Persistent organic pollutants (POPs) in pelagic systems. Ambio 29:202-209

Lauenstein GG, Cantillo AY (1993) Sampling and analytical methods of the National Status and Trends Program National Benthic Surveillance and Mussel Watch projects. 1984-1992. Silver Spring, MD, National Oceanic and Atmospheric Administration Technical Memorandum NOS ORCA 71

Long ER, Dutch M, Aasen S, Welch K, Hameedi MJ (2005) Spatial extent of degraded sediment quality in Puget Sound (Washington State, U.S.A.) based upon measures of the sediment quality triad. Environ Monit Assess 111:173-222

Matturro B, Ubaldi C, Rossetti S (2016) Microbiome dynamics of a polychlorobiphenyl (PCB) historically contaminated marine sediment under conditions promoting reductive dechlorination. Front Microbiol 7:1502

Meador JP, Collier TK, Stein JE (2002) Use of tissue and sedimentbased threshold concentrations of polychlorinated biphenyls (PCBs) to protect juvenile salmonids listed under the US Endangered Species Act. Aquat Conserv 12:493-516

Meador JP, Adams WJ, Escher BI, McCarty LS, McElroy AE, Sappington KG (2011) The tissue residue approach for toxicity assessment: findings and critical reviews from a society of environmental toxicology and chemistry Pellston Workshop. Integr Environ Assess Manag 7:2-6

Miller A, Hedman JE, Nyberg E, Haglund P, Cousins IT, Wiberg K, Bignert A (2013) Temporal trends in dioxins (polychlorinated dibenzo-p-dioxin and dibenzofurans) and dioxin-like polychlorinated biphenyls in Baltic herring (Clupea harengus). Mar Pollut Bull 73(1):220-230

Mongillo TM, Ylitalo GM, Rhodes LD, O'Neill SM, Noren DP, Hanson MB (2016) Exposure to a mixture of toxic chemicals: implications for the health of endangered Southern Resident killer whales. U.S. Dept. Commer, NOAA Tech. Memo. NMFSNWFSC-135. doi:10.7289/V5/TM-NWFSC-135

Moore SK, Mantua NJ, Newton JA, Kawase M, Warner MA, Kellogg JP (2008) A descriptive analysis of temporal and spatial patterns of variability in Puget Sound oceanographic properties. Estuar Coast Shelf Sci 80(4):545-554

Moser ML, Myers MS, West JE, O'Neill SM, Burke BJ (2013) English sole spawning migration and evidence for feeding site fidelity in Puget Sound, USA, with implications for contaminant exposure. Northwest Sci 87(4):317-325

Myers JM, Kope RG, Bryant GJ, Teel D, Lierheimeret LJ et al (1998) Status review of chinook salmon from Washington, Idaho, Oregon, and California. US Department of Commerce NOAA Technical Memorandum NMFS-NWFSC-35, Seattle, Washington

O’Neill SM, Moser ML, Myers MS, Quinnell SR, West JE (2007) Acoustic telemetry reveals daily movement patterns and annual homing migration to foraging habitats by English sole: application to management of contaminated sediments. Proceedings of the 2007 Puget Sound Georgia Basin Research Conference. http://depts.washington.edu/uwconf/2007psgb/2007proceedings/ papers/p12_oneil.pdf

O’Neill SM, West JE (2009) Marine distribution, life history traits, and the accumulation of polychlorinated biphenyls in Chinook salmon from Puget Sound, Washington. Trans Am Fish Soc 138(3):616-632

Osterberg DJ, Pelletier G (2015) Puget sound regional toxics model: evaluation of PCBs, PBDEs, PAHs, copper, lead and zinc. Washington Department of Ecology Report 15-03-025
Papale M, Giannarelli S, Francesconi S, Di Marco G, Mikkonen A et al (2016) Enrichment, isolation and biodegradation potential of psychrotolerant polychlorinated-biphenyl degrading bacteria from the Kongsfjorden (Svalbard Islands, high arctic Norway). Mar Poll Bull 114(2):849-859

Puget Sound Partnership (2016) Puget Sound vital signs: toxics in fish. http://www.psp.wa.gov/vitalsigns/toxics_in_fish.php

Rice CA, Duda JJ, Greene CM, Karr JR (2012) Geographic patterns of fishes and jellyfish in Puget Sound surface waters. Mar Coastal Fish 4(1):117-128

Ross PS (2006) Fireproof killer whales (Orcinus orca): flameretardant chemicals and the conservation imperative in the charismatic icon of British Columbia, Canada. Can J Fish Aquat Sci 63(1):224-234

Ross PS, Ellis GM, Ikonomou MG, Barrett-Lennard LG, Addison RF (2000) High PCB concentrations in free-ranging Pacific killer whales, Orcinus orca: effects of age, sex and dietary preference. Mar Pollut Bull 40:504-515

Ross PS, Jeffries SJ, Yunker MB, Addison RF, Ikonomou MG, Calambokidis JC (2004) Harbor seals (Phoca vitulina) in British Columbia, Canada, and Washington State, USA reveal a combination of local and global polychlorinated biphenyl, dioxin, and furan signals. Environ Toxicol Chem 23(1):157165

Ross PS, Couillard CM, Ikonomou MG, Johannessen SC, Lebeuf M, Macdonald RW, Tomy GT (2009) Large and growing environmental reservoirs of Deca-BDE present an emerging health risk for fish and marine mammals. Mar Pollut Bull 58(1):7-10

Ross PS, Noël M, Lambourn D, Dangerfield N, Calambokidis J, Jeffries S (2013) Declining concentrations of persistent PCBs, PBDEs, PCDEs, and PCNs in harbor seals (Phoca vitulina) from the Salish Sea. Prog Oceanogr 115:160-170

Sloan CA, Brown DW, Pearce RW, Boyer RH, Bolton JL, Burrows DG, Herman DP, Krahn MM (2004) Extraction, cleanup, and gas chromatography/mass spectrometry analysis of sediments and tissues for organic contaminants. NOAA Technical Memorandum NMFS-NWFSC-59

Sloan CA, Brown DW, Pearce RW, Boyer RH, Bolton JL, Burrows DG, Herman DP, Krahn MM (2005) Determining aromatic hydrocarbons and chlorinated hydrocarbons in sediments and tissues using accelerated solvent extraction and gas chromatography/mass spectrometry. In: Ostrander GK (ed) Aquatic toxicology, vol 2. CRC Press, Boca Raton, FL, pp 631-651

Sloan CA, Anulacion BF, Baugh KA, Bolton JL, Boyd D, Boyer RH, Burrows DG, Herman DP, Pearce RW, Ylitalo GM (2014) Northwest Fisheries Science Center's analyses of tissue, sediment, and water samples for organic contaminants by gas chromatography/mass spectrometry and analyses of tissue for lipid classes by thin layer chromatography/flame ionization detection. NOAA Technical Memorandum NMFS-NWFSC-125

Stow CA, Carpenter SR, Amrhein JF (1994) PCB concentration trends in Lake Michigan coho (Oncorhynchus kisutch) and chinook salmon (O. tshawytscha). Can J Fish Aquat Sci 50:1384-1390

SYSTAT (2007) SYSTAT 12. Systat Software Inc, San Jose

Szlinder-Richert J, Barska I, Mazerski J, Usydus Z (2009) PCBs in fish from the southern Baltic Sea: levels, bioaccumulation features, and temporal trends during the period from 1997 to 2006. Mar Pollut Bull 58(1):85-92

Thomson RE (1994) Physical oceanography of the Strait of GeorgiaPuget Sound-Juan de Fuca Strait system. Review of the marine environment and biota of Strait of Georgia, Puget Sound, and Juan de Fuca Strait. In: Proceedings of the BC/Washington symposium on the marine environment, Jan 13, 14, 1994. Can Tech Rep Fish Aquat Sci Report No. 1948 
Tierney KB, Kennedy JC, Gobas F, Gledhill M, Sekela M (2014) Organic contaminants and fish. In: Tierney KB, Farrell AP, Brauner CJ (eds) Organic chemical toxicology of fishes: Fish Physiology, vol 33. Elsevier Academic Press, Amsterdam

Tomy GT, Palace VP, Halldorson T, Braekevelt E, Danell R et al (2004) Bioaccumulation, biotransformation, and biochemical effects of brominated diphenyl ethers in juvenile lake trout (Salvelinus namaycush). Environ Sci Technol 38:1496-1504

Washington Department of Ecology (2006) Washington State polybrominated diphenyl ether (PBDE) Chemical Action Plan: Final Plan. Washington Department of Ecology Report 05-07-048. p 328. http://www.ecy.wa.gov/biblio/0507048.html

Washington Department of Health (2015) Puget Sound fish consumption advice. Washington Department of Health, Division of Environmental Health, Office of Environmental Health Assessments. Olympia, Washington. http://www.doh.wa.gov/Portals/1/ Documents/Pubs/334-098.pdf

West JE, O'Neill SM, Ylitalo GM (2008) Spatial extent, magnitude, and patterns of persistent organochlorine pollutants in Pacific herring (Clupea pallasi) populations in the Puget Sound (USA) and Strait of Georgia (Canada). Sci Total Environ 394(2-3):369-378

West JE, Lanksbury J, O'Neill SM (2011a) Persistent organic pollutants in marine plankton from Puget Sound, Washington Department of Ecology report no. 11-10-002

West JE, Lanksbury J, O’Neill SM, Marshall A (2011b) Persistent, bioaccumulative and toxic contaminants in pelagic marine fish species from Puget Sound. Washington Department of Ecology report no. 11-10-003

Wickham JD, Stehman SV, Gass L, Dewitz J, Fry JA, Wade TG (2013) Accuracy assessment of NLCD 2006 land cover and impervious surface. Remote Sens Environ 130:294-304

Ylitalo GM, Buzitis J, Krahn MM (1999) Analyses of tissues of eight marine species from Atlantic and Pacific coasts for dioxin-like chlorobiphenyls (CBs) and total CBs. Arch Environ Contam Toxicol 37:206-219 